\title{
Influence of Foliar Applied Mineral and Bio- fertilizers on the Yield Parameters of Eig and Olive Trees Grown in the Northwestern Coast of Egypt
}

\author{
H.A. Fawy and Mona M. El-Shazly
}

Soil Fertility and Microbiology Dept., Desert Research Center (DRC), Cairo, Egypt

\begin{abstract}
7 HIS STUDY was carried out through two sequences years in some valleys of the north-western coast, Matrouh Governorate, Egypt. Two farms were studied, the first farm was cultivated with figs trees in El Gabally valley located at $31^{\circ} 54.97^{\prime} 26^{\prime \prime} \mathrm{N}$ and $26^{\circ}$ $13.13^{\prime} 37^{\prime \prime} \mathrm{E}$, while the other farm was cultivated with olives trees in Habes valley located at $31^{\circ} 21.84^{\prime} 21^{\prime \prime} \mathrm{N}$ and $27^{\circ} 34.81^{\prime} 02^{\prime \prime} \mathrm{E}$. The chosen trees of both plants nearly are similar. The texture soils in both farms were sandy loam. The main source of irrigation water for the figs and olives trees is seasonal of water rain. Some additions of irrigation water were applied from the found wells. The area of figs trees 8 years old was $(11 \times 11 \mathrm{~m})$, i.e, $121 \mathrm{~m}^{2}$ (35 trees/fed), while the area of olive trees 10 years old was $(10 \mathrm{x} 10 \mathrm{~m})$, i.e, $100 \mathrm{~m}^{2}(42$ trees/fed). The aim of this study is using the integration between foliar mineral and bio-fertilizers(Azotobacter chroococcum,Bacillus megatherium and Sacchromyces cervisiae to approach the maximum yield (quantity and quality) of fig and olive fruits by using different doses of the studied fertilizers to raise the efficiency of these fertilizers under the conditions of North Western Coast soils.
\end{abstract}

The results obtained assure that the foliar application of NPK, micronutrients and bio-fertilizer application increased the yield components, total antioxidants, total phenols and nutrients concentration of leaves and fruits of both figs and olive trees. The treatments arranged in the descending order according to the power effect on fruits yield of fig and olive trees as following; NPK fertilizer > micronutrients fertilizers > bio-fertilizers > control. The most effective treatment was $\mathrm{Bio}_{1} \mathrm{Fol}_{4}$ with $\mathrm{Micro}_{2}$ which achieved 13.9 and 5.05 ton fruits/fed for figs and olive trees respectively. The foliar application of bio-fertilizers in the presence of mineral fertilizers recorded higher increases of yield parameters and nutrients content in leaves and fruits of both plants. The NPK fertilizers are the most influential on nutrients concentration, total phenols, total antioxidants activity, total sugar content $(\%)$ and oil content $(\%)$ of figs and olives fruits when compared with the other studied treatments and control. The foliar application of micronutrients fertilizers took the same trend of NPK fertilizers effect.

Keywords: Integration of foliar mineral and bio-fertilizers, Fig and olive fruits, Valleys in the North-Western Coast, Matrouh Governorate, Egypt 
The main source of irrigation water to fig and olive trees in the North-western Coast of Matrouh Province is rains water which is starting from October or November until February and March every year. In some areas, possible use supplementary irrigation water system from wells water after the rainy season is ens. The most soils of the Northwestern Coast are calcareous soils which are different in the calcium carbonate content from one region to another.

Regarding to the mineral fertilizers functions in plant; the macronutrients functions in plant such as; the photosynthetic processes in leaves and plant growth were remarkably improved by high nitrogen nutrition. Nitrogen contributes greatly in the formation of the following, protein synthesis, necessary component in cell structure, leafy growth and carbohydrate production (Cechin \& Fumis, 2004 and Weisany et al., 2013). Phosphorus involved in the photosynthesis, energy and nutrient transport in plant, it can establish a strong root base and produce strong all through the growth plant stages (Ceulemans et al., 2011 and Lambers et al., 2014). Potassium is involved in many processes in plant such as photosynthesis, water retention and uptake of the plant, protects plant from frost, reduce it disease in root, shoots and leaves of the plant, has good characteristics quality such as producing of uniform size, color and maturity, with enhanced flavor, free of blemishes and devoid of any sign of diseases (Britto and Kronzucker, 2008 and Wang et al., 2013).

The micronutrients functions in plant such as; Iron $(\mathrm{Fe})$ involves for many processes in plant such as the process of absorption from the soil through the roots, control transfers from the roots to the parts of the plant above soil surface, the intensification of the iron concentration in the mitochondria and chloroplasts and during seed germination and reduce the presence of iron in the wood (Conte and Walker, 2011). Iron deficiency leads to facilitate the transfer of heavy metal such as manganese, zinc, cobalt, and cadmium, while sufficient level or above of iron prevents it (Barberona et al., 2014). Plant's ability to withhold iron and redistribute within the plant for non-iron link the causes of infectious diseases to the presence of competing on the iron link between them and thus increase the plant's ability to cope with such infectious diseases (Expert et al., 2012). Manganese (Mn) plays an important role for many processes in plant such as oxidation and reduction processes in plants, such as the electron transport in photosynthesis, in chlorophyll production, as an activating for more 35 different enzymes and carbohydrates synthesis (Mousavi et al., 2011). Zn influences the activity of plant enzymes, hydrogenase, carbonic anhydrase and synthesis of cytochrome, $\mathrm{Zn}$ involves in plant carbohydrate metabolism, maintenance of the integrity of cellular membranes, protein synthesis, regulation of auxin synthesis and pollen formation, $\mathrm{Zn}$ has positive effect on water uptake and transport in plants and also reduces the adverse effects of short periods of heat and salt stress, $\mathrm{Zn}$ is required for the synthesis of growth hormone auxin, IAA and integrity of cellular membranes (Hafeez et al., 2013).

Egypt. J. Soil Sci. 56, No. 1 (2016) 
Regarding to the effect of mineral fertilization on fruits of figs and olive plants, Mimoun et al. (2008) stated that the foliar application of $\mathrm{K}$ increased the yield and oil yield of rainfed olive. Barranco et al. (2010) stated that the foliar mono-potassium phosphate (MKP) 3\% plus urea was the most effective treatment for yield and oil content of olive fruits, and improved $\mathrm{P}$ and $\mathrm{K}$ nutritional state of olive. Yousef et al. (2011) stated that the most effective treatment for yield components and nutrients content of olive trees was when micro elements ( $\mathrm{Zn}, \mathrm{Mn}$ and $\mathrm{Fe}$ ) foliar applied at $0.25 \%$ with amino acids at $0.5 \%$. Hagagg et al. (2012) decided that the foliar application with $50 \mathrm{~g}$ $\left(20 \mathrm{~N} / 20 \mathrm{P}_{2} \mathrm{O}_{5} / 20 \mathrm{~K}_{2} \mathrm{O}\right)$ as $(37.5 \mathrm{~g}$ in soil $+12.5 \mathrm{~g}$ foliar application) improved percentage of leaves number, leaves dry weight and root length, while the highest number and weight of olive fruits achieved with adding (12.5g in soil + $37.5 \mathrm{~g}$ as foliar application). Malek and Sanaa (2013) reported that the average weight of the fruit per tree, oil content and yield of olive fruits increased with increasing application of NPK fertilizer. Tekaya et al. (2013) reported that the foliar fertilizers showed as the following; T3 (rich in P and K), and T6 (rich in $\mathrm{N}, \mathrm{B}, \mathrm{Mg}, \mathrm{S}, \mathrm{Mn}, \mathrm{P}, \mathrm{Ca}$ and $\mathrm{K}$ ) improved oil stability by increasing the content of antioxidants, while $\mathrm{T} 2$ (rich in $\mathrm{B}, \mathrm{Mg}, \mathrm{S}$ and $\mathrm{Mn}$ ) and $\mathrm{T} 4$ (rich in $\mathrm{P}$ and $\mathrm{Ca}$ ) affected negatively the antioxidant content in olive oils. Mujić et al.(2012) stated that the total phenolics content in fig fruits extracted by $70 \%$ methanol varied from 7.24 to $11.17 \mathrm{mg}$ CAE/g of dry extract. Yaz et al (2012) reported that the average fig fruits weight ranged between $21.17-69.25 \mathrm{~g}$, while fruit width ranged between 31.91-50.88 mm. Jagtap et al. (2012) stated that the application of $\mathrm{FeSO}_{4}, \mathrm{ZnSO}_{4}$ and $\mathrm{B}$ to fig trees recorded significantly higher yield parameters like number of fruits per plant (227), average fruit weight $(62.58 \mathrm{~g})$ and yield $(14.01 \mathrm{~kg} /$ tree $)$. Ercisli et al. (2012) reported that the total phenols ranged from 24 to $237 \mathrm{mg}$ of gallic acid equivalent per $100 \mathrm{~g}$ fresh weight of fig fruits, while the total antioxidant ranged from 4.6 to $18.7 \mathrm{mmol}$ $\mathrm{Fe}_{2}$ (ferric reducing ability equivalent to $1 \mathrm{mmol} / \mathrm{L} \mathrm{FeSO}$ ) $/ \mathrm{kg} \mathrm{FW}$ of fig fruits. Sulaiman and Hassan (2011) reported that the total sugar of fig fruits ranged from 20 to $31 \%$, generally the nutrients content in fig fruits were 572, 222, 152 , 5.3, 0.38, 8.6, 44.7 and $7.5 \mathrm{mg} / 100 \mathrm{~g} \mathrm{FW}$ for $\mathrm{K}, \mathrm{Ca}, \mathrm{P}, \mathrm{Fe}, \mathrm{Cu}, \mathrm{Zn}, \mathrm{Mg}$ and $\mathrm{Na}$ respectively.

Concerning to the important role of bio-fertilizers and effect foliar application on fruits yield of fig and olive trees; Gajbhiye et al. (2003) reported that the foliar application of bio-fertilizers produced biological compounds in plants like hormones such as auxin, gibberellic acid, cytokinins acid and vitamins, which improved fruit yield and increase nutrient contents. Thuler et al. (2003) decided that the Azospirillum sp. ability to release plant growth regulators (PGR) such as polyamines, ethylene, indoleacetic acid and amino acids, the type and quantity of the released substances varied, depending on the presence of combined-N in the medium. Revillas et al. (2005) stated that the Azotobacter was not only fixed nitrogen but also produce amino acids, organic acids, vitamins, antimicrobial substances and increased microbial community and plant growth. The foliar application of plant growth promoting rhizobacteria (PGPR) such as Azospirillium, Azotobacter, Bacillus and Rhizobium improved yield increases of plants and product

Egypt. J. Soil Sci. 56, No. 1 (2016) 
plant form fungal diseases (Basha et al., 2006 and Esitken et al., 2006). Biofertilization leads to the activation of photosynthetical processes and increased activity of peroxidase enzyme in plants (Winget and Gold, 2007). Vijayan et al. (2007) reported that the foliar application of Azotobacter chroococcum alleviated from harmful salinity effect to plant growth Spraying plants with effective microorganisms liquid can increase the leaf area, stem thickness and chlorophyll content (Xiaohou et al., 2008). Osman (2010) reported that the soil and foliar application of both bio and NPK fertilizers significantly increased amino acid content, mineral content and total carbohydrates of olive leaves. Eleiwa et al. (2012) reported that the foliar application of bio-fertilizers(Azospirillum, Azotobacter or Bacillus ) in combination with micronutrients $(\mathrm{Mn}+\mathrm{Fe}+\mathrm{Zn})$ can lead to highest yield components of plants. Maksoud et al. (2012) reported that the best treatment was superiority with adding compost $30 \%$ with bacterial suspension of Azotobacter chroococcum for vegetative growth, yield and flesh oil content of olive fruits. Jan et al. (2014) decided that the application of Azotobacter sp. with organic fertilizers (farmyard manure and liquid organic Fertilizer) improved morphology and growth characters and nutrients content of plants. Abd El-Gawad 2014 reported that microbial inoculants improved fertilization, increase the number and biological activity of desired microorganisms. The objective of this study is approaching the maximum yield of the fig and olive trees in some of the North Western Coast regions, by using mineral and bio fertilizers integration.

\section{Material and Methods}

Throughout two successive years, two completely randomized split-split blocks field experiments with three replications for each treatment were carried out. Two farms were used, the first farm was cultivated with fig trees in El Gabally valley located at $31^{\circ} 54.97^{\prime} 26^{\prime \prime} \mathrm{N}$ and $26^{\circ} 13.13^{\prime} 37^{\prime \prime} \mathrm{E}$, while the other was cultivated with olive trees in Habes valley located at $31^{\circ} 21.84^{\prime} 21^{\prime \prime} \mathrm{N}$ and $27^{\circ} 34.81^{\prime} 02^{\prime \prime}$ E, which selected to obtain the homogeneity or symmetry between trees. The texture farm soils was sandy loam, the main source of irrigation water for the plants is the seasonal rain water. Some additions of irrigation water from wells in valley. The area of figs trees 8 years old was $(11 \mathrm{x} 11 \mathrm{~m})$, i.e, $121 \mathrm{~m}^{2}$ (35 trees/fed), while area of olive trees 10 years old was $(10 x 10 \mathrm{~m})$, i.e, $100 \mathrm{~m}^{2}$ (42 trees/fed). Analytical data of the studied soils are presented in table (1). Analyses were accomplished according to Page et al. (1984) and Klute (1986).

The foliar application of bio-fertilizers was plant growth promoting rhizobacteria (PGPR) as fresh liquid culture mixed from Azotobacter chroococcum ,Bacillus megatherium and Sacchromyces cervisiae concentrated at $10^{8}$ colony forming unit (cfu/ml) and foliar application at two rate $(0$ and $2 \mathrm{~L} / 600 \mathrm{~L})$ for both fig and olive trees at the same time of mineral application. The previous bio-fertilizers were subjected to different biochemical tests for screening their hormonal and enzymatic activity and identified (Table 3). Microbiological analysis for count and density in plant were determination according to Nautiyal (1999) and modified Ashby's media (Hill, 2000). Table 3 shows the biochemical

Egypt. J. Soil Sci. 56, No. 1 (2016) 
activities of the Azotobacter chroococcum and Bacillus megatherium characterizes in Laboratory which used in the field experiment to produce of hormones, enzymes. The selected isolates (Azotobacter chroococcum and Bacillus megatherium) were subjected to different biochemical tests for screening their hormonal (Rizzolo et al. 1993) and enzymatic activity (Barrow and Veltham 1993). Selected Azotobacter and PDB isolates were purified and identified according to Bergy's manual of determinative bacteriology (1994). Hormonal activities and enzyme production are common features of all the tested microorganisms (El- Saidy and Abd El-Hai, 2011).

TABLE 1. Some of chemical and physical properties of the studied soils.

\begin{tabular}{|c|c|c|c|c|c|c|c|c|c|}
\hline \multirow{2}{*}{$\begin{array}{l}\text { Depth } \\
\text { Cm }\end{array}$} & \multirow{2}{*}{$\begin{array}{l}\mathrm{pH} \\
1: 1\end{array}$} & \multirow{2}{*}{$\begin{array}{c}\text { EC } \\
\text { dS/m }\end{array}$} & $\mathbf{O M}$ & $\mathrm{CaCO}_{3}$ & Sand & Silt & Clay & \multirow{2}{*}{\begin{tabular}{c|}
$\mathrm{CEC}$ \\
$\mathrm{me} / 100 \mathrm{~g}$
\end{tabular}} & \multirow{2}{*}{ Texture } \\
\hline & & & \multicolumn{5}{|c|}{$\%$} & & \\
\hline \multicolumn{10}{|c|}{ El Gabally Valley (Figs farm) } \\
\hline $0-30$ & 8.04 & 1.70 & 4.56 & 16.62 & 61.11 & 20.57 & 18.32 & 16.80 & S.L \\
\hline $\begin{array}{l}30 \\
60\end{array}$ & 7.96 & 1.21 & 1.55 & 17.52 & 59.01 & 21.24 & 19.75 & 18.20 & S.L \\
\hline \multicolumn{10}{|c|}{ Habes Valley (olives farm) } \\
\hline $0-30$ & 8.22 & 1.76 & 3.89 & 12.34 & 71.14 & 11.50 & 17.36 & 11.89 & S.L \\
\hline $\begin{array}{l}30- \\
60\end{array}$ & 7.95 & 1.65 & 1.19 & 12.43 & 70.92 & 11.35 & 17.73 & 12.15 & S.L \\
\hline \multicolumn{10}{|c|}{ Soluble cations and anions (me/L) and Total antioxidants and phenol acids in soil } \\
\hline \multicolumn{10}{|c|}{ El Gabally Valley (Figs farm) } \\
\hline & $\mathrm{Na}$ & $\mathrm{K}$ & $\mathrm{Ca}$ & $\mathrm{Mg}$ & $\mathrm{HCO}_{3}^{-1}$ & $\mathrm{Cl}^{-1}$ & $\mathrm{SO}_{4}^{-2}$ & T. phenol & $\begin{array}{l}\text { T.A. } \\
\text { A }\end{array}$ \\
\hline $0-30$ & 8.70 & 0.22 & 4.50 & 3.70 & 0.80 & 11.30 & 5.02 & 695 & 182 \\
\hline $30-60$ & 4.50 & 0.40 & 4.00 & 3.00 & 0.80 & 8.10 & 3.00 & 325 & 92 \\
\hline \multicolumn{10}{|c|}{ Habes Valley (olives farm) } \\
\hline $0-30$ & 5.10 & 0.58 & 6.40 & 5.50 & 0.60 & 12.00 & 4.98 & 514 & 167 \\
\hline $30-60$ & 4.65 & 0.54 & 6.00 & 5.30 & 0.60 & 11.20 & 4.69 & 296 & 84 \\
\hline & & & & Ivailable & utrients & $\mathrm{ng} / \mathrm{kg}$ ) in & soil & & \\
\hline & $\mathrm{N}$ & & 5 & K & & & $\mathrm{Mn}$ & $\mathrm{Zn}$ & $\mathrm{Cu}$ \\
\hline & & & & El Gaba & y Valle & Figs farm & & & \\
\hline $0-30$ & 49.5 & & 2.84 & 169 & & & 5.24 & 2.89 & 0.98 \\
\hline $30-60$ & 27.8 & & .56 & 187 & & & 6.69 & 3.11 & 1.03 \\
\hline & & & & Habes & alley $(\mathrm{c}$ & ves farm) & & & \\
\hline $0-30$ & 39.6 & & .95 & 136 & & & 3.82 & .54 & 0.63 \\
\hline $30-60$ & 20.5 & & .14 & 147 & & & 4.16 & .72 & 0.76 \\
\hline & tial nutr & ents ar & bioch & ical cont & ths of le & es before & applied any & ttilizers $(\mathrm{mg} / \mathrm{l}$ & $/ \mathrm{kg})$ \\
\hline Eorms & $\mathrm{N}$ & $\mathrm{P}$ & $\mathrm{K}$ & $\mathrm{Fe}$ & $\mathrm{Mn}$ & $\mathrm{Zn}$ & $\mathrm{Cu}$ & T. phenol & T.A.A \\
\hline Farms & & & & & $/ \mathrm{kg}$ & & & $\mu \mathrm{g} / \mathrm{r}$ & $\mathrm{ml}$ \\
\hline Figs & 0.87 & 0.09 & 0.73 & 48.6 & 44.6 & 26.5 & 1.78 & 324 & 167 \\
\hline Olives & 0.76 & 0.07 & 0.67 & 39.8 & 36.2 & 18.3 & 1.68 & 491 & 245 \\
\hline
\end{tabular}

$\mathrm{SL}=$ Sandy Loam soil, T.ph (Total phenol antioxidants) $=\mu \mathrm{mol}$ of Gallic acid $/ \mathrm{ml}$ extract, T.A.A (Total antioxidants activity) $=\mu \mathrm{g}$ of Ascorbic acid $/ \mathrm{ml}$ extract. 
TABLE 2. The foliar mineral and bio-fertilizers for fig and olive trees of the studied soils

\begin{tabular}{|c|c|c|c|c|c|c|}
\hline \multirow{2}{*}{$\begin{array}{c}\text { Foliar } \\
\text { Treatments }\end{array}$} & \multicolumn{3}{|c|}{ Figs } & \multicolumn{3}{|c|}{ Olive } \\
\hline & $\mathbf{N}$ & $\mathbf{P}$ & $\mathbf{K}$ & $\mathbf{N}$ & $\mathbf{P}$ & $\mathbf{K}$ \\
\hline \multicolumn{7}{|c|}{$\begin{array}{l}\text { Equal doses of the three fertilizers treatments applied during three growth stages } \\
\qquad(\mathrm{ppm} / 600 \mathrm{~L})\end{array}$} \\
\hline Foliar1 & 917 & 181 & 625 & 750 & 362 & 556 \\
\hline Foliar2 & 1000 & 254 & 903 & 833 & 435 & 625 \\
\hline Foliar3 & 1167 & 290 & 1042 & 1083 & 652 & 764 \\
\hline
\end{tabular}

Different doses of the one fertilizers treatment $\left(\mathrm{Fol}_{4}\right)$ applied during three growth stages

\begin{tabular}{|l|c|c|c|c|c|c|}
\hline \multicolumn{7}{|c|}{$(\mathrm{ppm} / 600 \mathrm{~L})$} \\
\hline Dose A & 1017 & 196 & 799 & 933 & 471 & 694 \\
\hline Dose B & 833 & 217 & 903 & 750 & 580 & 799 \\
\hline Dose C & 675 & 254 & 1042 & 583 & 725 & 903 \\
\hline \multicolumn{7}{|c|}{ Micronutrients treatments (ppm/600L) } \\
\hline Micro 1 & 200 ppm of Fe, Mn and Zn \\
\hline Micro 2 & Bio-fertilizers \\
\hline \multicolumn{7}{|c|}{} \\
\hline Bio & 2L of bio-fertilizer/600L applied at the same times of mineral fertilizers \\
\hline
\end{tabular}

TABLE 3. Biochemical activity of bio-fertilizers .

\begin{tabular}{|c|c|c|c|c|c|c|c|c|}
\hline \multirow{3}{*}{$\begin{array}{c}\text { Isolate } \\
\text { microorganisms }\end{array}$} & \multirow{2}{*}{\multicolumn{3}{|c|}{$\begin{array}{c}\begin{array}{c}\text { Hormonal activity } \\
\text { Quantitative }\end{array} \\
(\mu \mathrm{g} / \mathrm{ml}) \\
\end{array}$}} & \multirow{2}{*}{\multicolumn{4}{|c|}{ Enzyme activity }} & \multirow{3}{*}{$\begin{array}{l}\text { Total N } \\
(\mathrm{ppm}) \\
\end{array}$} \\
\hline & & & & & & & & \\
\hline & IAA & $\mathrm{GA}_{3}$ & Cytokinin & $\begin{array}{l}\text { Amy } \\
\text {-lase }\end{array}$ & Cellulase & Protease & Pectinase & \\
\hline $\begin{array}{l}\text { Azotobacter } \\
\text { chrococcum }\end{array}$ & 0.18 & 3.4 & 27 & +++ & - & + & + & 132 \\
\hline B. megatherium & 0.24 & 1.32 & 12 & + & + & ++ & ++ & . \\
\hline
\end{tabular}

positive $=+$, negative $=$ -

The foliar application of mineral and bio-fertilizers added during the different stages of fig and olive growth as following: the first dose of mineral fertilizers was added during vegetative growth stage before flowering growth stage, second dose was added after the flowering stage and the beginning of the fruit composition stage during May and July months, while third dose was added during the June and August months.

The equal three doses of the three mineral fertilizers treatments applied three times during three stages were (foliar 1,2 and 3) while the different three doses (one integration treatment) applied one time during three stages were (dose A, B and $\mathrm{C})\left(\mathrm{Fol}_{4}\right)$, the above information described in Table (2). The equation to calculation the nutrients concentration in foliar solutions as following:

Nutrient concentration $(\%)$ in foliar solution $=100 \times(\mathrm{Q}$ of fertilizer $(\mathrm{kg}) \mathrm{X}$ $\%$ of nutrient in fertilizers/100) / water volume (600L). To convert from \% to ppm by multiplied $x$ 10000. To convert $\mathrm{P}_{2} \mathrm{O}_{5}$ to $\mathrm{P}$ divide $/ 2.3$ and $\mathrm{K}_{2} \mathrm{O}$ to $\mathrm{K}$ divide /1.2 while $\mathrm{N}$ divide /1. 
Plant samples collected at harvesting stage in the end of each experiment. The fruits yield, numbers and weight of fruits of both fig and olive plants recorded during the studied two seasons. Plant samples were analyzed for $\mathrm{N}, \mathrm{P}$ and $\mathrm{K}$ according to Cottenie et al. (1982). The official Lane-Eynon method described in AOAC was used to measure the fruits total sugar (TS \%) (James, 2004 and Horowitz, 2000), while the oil was extracted from the olive fruits samples using chloroform: methanol mixture $(2: 1, \mathrm{~V} / \mathrm{V})$ and SOXHLET extraction method according to the method described by Kates (1972) and Petrakis (2006). Measurements of total antioxidants and total phenolic acids in both soils and plants were done according to Rimmer (2009). Statistical analysis was carried out using spilt-split design with three replications for each treatment. The obtained data were statistically analyzed according to Gomez and Gomez (1984).

\section{Results and Discussion}

Effect mineral and bio-fertilizers on fruits yield of figs and olive plants

The nutrition status of fig and olive leaves grown at El Gabally and Habes valleys respectively before applied any fertilizers besides the available nutrients in the two studied farms are presented in Table 1, these nutrients were available for trees at rain season only (three months) but, in the other months the soil will be dried, must be added supplemental irrigation water with nutrients to continue plant life, complete plant growth and fruits production of both fig and olive plants.

Concerning the effect of foliar NPK fertilizers and bio-fertilizer treatments on the yield components of figs and olive trees, data in Table 4 showed that the yield parameters of both fig and olive plants increased with increasing application rates of NPK treatments $\left(\mathrm{Fol}_{1}, \mathrm{Fol}_{2}\right.$ and $\left.\mathrm{Fol}_{3}\right)$. The fertilizer treatment which integrated with growth stages of plants $\left(\mathrm{Fol}_{4}\right)$ recorded higher fruits yield of both fig and olive trees than other NPK foliar treatments by about 7.9, 5.5 and $14.9 \%$ for number branches, number fruits and weight of one fruit $(\mathrm{g}) /$ fig tree respectively, while being $10.1,2.9$ and $15.3 \%$ of olive tree.

Bio-fertilizer application with mineral fertilizers indicated higher increase of the fruits yield for both fig and olives trees than single application and control by about $9,3.4$ and $5.7 \%$ for branches number, number and weight of fruits (g)/fig tree respectively, while being $11.9,7.3$ and $10.2 \%$ of olive trees. These results were due to important roles of bio-fertilizers in plant where regular growth plant and improved yield parameter of fig and olive fruits, these facts reported by Mehmet et al., (2008), Nourali et al. (2011), Jagtap et al. (2012), Hagagg et al. (2012) and Tekaya et al. (2013).

Regarding to the effect of foliar application of micronutrients and bio-fertilizers on fruits yield components, the foliar applied of micronutrients increased the fruits yields of both fig and olive trees with increasing micronutrients rate by about 7.9, 5.5 and $14.9 \%$ for number of branches, number of fruits and weight of one fruit 
(g)/fig trees respectively, while being 10.1, 2.9 and $15.3 \%$ in olive plants. The foliar application of micronutrients and bio-fertilizers recorded higher increase of yield parameters with adding the highest rates of them.

Interaction effect among the studied three factors achieved the highest fruits yield of both fig and olive plants. Therefore the superior treatment was $\mathrm{Bio}_{1} \mathrm{Fol}_{4}$ with $\mathrm{Micro}_{2}$ which achieved 13.9 and 5.05 ton fruits /fed for fig ( 35 trees/fed) and olive (42 trees/fed) respectively, and increased all the studied yield parameters than control treatment by about 29.1, 20.2 and $25.6 \%$, for branches number, fruits number and weight of fruits $(\mathrm{g})$ of fig plants respectively, while being 25.0, 15.4 and $20.5 \%$, for olive plants. The highest yield components of both fig and olive fruits were achieved by superior treatment $\mathrm{Bio}_{1} \mathrm{Fol}_{4} \mathrm{Micro}_{2}$ when compensation with other studied treatments.

TABLE 4. Effect of foliar mineral and bio-fertilizers applications on the yield components of both fig and olive trees (average of the two seasons).

\begin{tabular}{|c|c|c|c|c|c|c|c|c|c|}
\hline & \multirow[t]{3}{*}{ 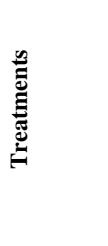 } & $\begin{array}{l}\dot{0} \\
\stackrel{0}{Z} \\
\stackrel{0}{E}\end{array}$ & 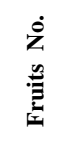 & 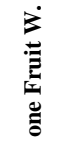 & 童 & 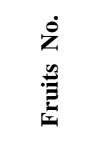 & 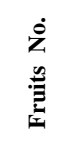 & 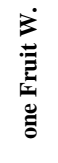 & $\stackrel{3}{:}$ \\
\hline & & /branch & /tree & (g) & ton/fed & /branch & /tree & (g) & ton/fed \\
\hline & & \multicolumn{4}{|c|}{ Figs trees } & \multicolumn{4}{|c|}{ Olive trees } \\
\hline \multicolumn{2}{|c|}{ Control } & 44 & 1540 & 29.2 & 1.6 & 135 & 4050 & 2.95 & 0.50 \\
\hline \multirow{9}{*}{$\stackrel{\overline{0}}{\stackrel{0}{Z}}$} & $\mathrm{Bio}_{0} \mathrm{Fol}_{1}$ & 58 & 2668 & 38.4 & 3.6 & 156 & 6396 & 4.18 & 1.12 \\
\hline & $\mathrm{Bio}_{0} \mathrm{Fol}_{2}$ & 64 & 3392 & 45.6 & 5.4 & 179 & 8413 & 4.95 & 1.75 \\
\hline & $\mathrm{Bio}_{0} \mathrm{Fol}_{3}$ & 69 & 4071 & 52.5 & 7.5 & 191 & 10314 & 5.89 & 2.55 \\
\hline & $\mathrm{Bio}_{0} \mathrm{Fol}_{4}$ & 74 & 4736 & 58.3 & 9.7 & 208 & 12480 & 6.76 & 3.54 \\
\hline & $\mathrm{Bio}_{1} \mathrm{Fol}_{0}$ & 49 & 1862 & 31.3 & 2.0 & 127 & 3556 & 3.57 & 0.53 \\
\hline & $\mathrm{Bio}_{1} \mathrm{Fol}_{1}$ & 61 & 2989 & 42.2 & 4.4 & 162 & 7452 & 4.57 & 1.43 \\
\hline & $\mathrm{Bio}_{1} \mathrm{Fol}_{2}$ & 67 & 3819 & 48.5 & 6.5 & 185 & 9805 & 5.38 & 2.22 \\
\hline & $\mathrm{Bio}_{1} \mathrm{Fol}_{3}$ & 73 & 4599 & 55.6 & 8.9 & 198 & 11682 & 6.35 & 3.12 \\
\hline & $\mathrm{Bio}_{1} \mathrm{Fol}_{4}$ & 78 & 5382 & 62.4 & 11.8 & 212 & 13780 & 7.19 & 4.16 \\
\hline \multirow{9}{*}{ 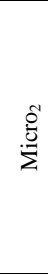 } & $\mathrm{Bio}_{0} \mathrm{Fol}_{1}$ & 63 & 3213 & 43.1 & 4.8 & 167 & 7515 & 5.13 & 1.62 \\
\hline & $\mathrm{Bio}_{0} \mathrm{Fol}_{2}$ & 69 & 4002 & 49.3 & 6.9 & 189 & 9639 & 5.82 & 2.36 \\
\hline & $\mathrm{Bio}_{0} \mathrm{Fol}_{3}$ & 75 & 4800 & 55.5 & 9.3 & 204 & 11832 & 6.69 & 3.32 \\
\hline & $\mathrm{Bio}_{0} \mathrm{Fol}_{4}$ & 79 & 5451 & 61.8 & 11.8 & 214 & 13696 & 7.41 & 4.26 \\
\hline & $\mathrm{Bio}_{1} \mathrm{Fol}_{0}$ & 53 & 2279 & 36.5 & 2.9 & 128 & 4224 & 4.13 & 0.73 \\
\hline & $\mathrm{Bio}_{1} \mathrm{Fol}_{1}$ & 67 & 3685 & 46.3 & 6.0 & 175 & 8575 & 5.57 & 2.01 \\
\hline & $\mathrm{Bio}_{1} \mathrm{Fol}_{2}$ & 73 & 4526 & 52.6 & 8.3 & 203 & 11165 & 6.37 & 2.99 \\
\hline & $\mathrm{Bio}_{1} \mathrm{Fol}_{3}$ & 78 & 5304 & 57.7 & 10.7 & 211 & 13082 & 7.27 & 3.99 \\
\hline & $\mathrm{Bio}_{1} \mathrm{Fol}_{4}$ & 83 & 6059 & 65.4 & 13.9 & 222 & 15318 & 7.85 & 5.05 \\
\hline \multicolumn{2}{|c|}{ LSD $_{0.05}$ Fol. } & 0.5 & 58 & 0.49 & 0.16 & 1.67 & 173 & 0.06 & 0.06 \\
\hline \multicolumn{2}{|c|}{ LSD $_{0.05}$ Bio. } & 0.47 & 56 & 0.39 & 0.14 & 1.30 & 155 & 0.06 & 0.06 \\
\hline \multicolumn{2}{|c|}{ LSD $_{0.05}$ Micro. } & 1.23 & 152 & 0.87 & 0.39 & 2.48 & 292 & 0.19 & 0.15 \\
\hline \multicolumn{2}{|c|}{$\mathrm{LSD}_{0.05} \mathrm{FxB}$} & 0.86 & 101 & 0.84 & 0.27 & 2.89 & 300 & 0.11 & 0.11 \\
\hline \multicolumn{2}{|c|}{$\operatorname{LSD}_{0.05} \mathrm{FxM}$} & 0.71 & 82 & 0.69 & 0.22 & 2.36 & 245 & 0.09 & 0.09 \\
\hline \multicolumn{2}{|c|}{$\mathrm{LSD}_{0.05} \mathrm{BxM}$} & 0.66 & 79 & 0.55 & 0.2 & 1.84 & 150 & 0.09 & 0.08 \\
\hline \multicolumn{2}{|c|}{ LSD $_{0.05} 3$ factors } & 1.22 & 142 & 1.19 & 0.39 & 3.05 & 317 & 0.15 & 0.11 \\
\hline
\end{tabular}

No=number, W=weight, Fol=foliar NPK fertilizers, Bio=bio-fertilizer and Micro= micronutrients fertilizers.

Egypt. J. Soil Sci. 56, No. 1 (2016) 
The third interaction was significant most influential on yield components of fig and olive trees above the second interaction which was greater impact than single interaction. The previous results indicated that the macronutrients treatments are the most influential on the trees fruits production of both fig and olive plants, followed by micronutrients and the least was bio-fertilizers. These due to the macronutrients have an important role to increase the ability of olive and fig trees to form cells which reflected on growth and production of plants, these facts agreed with reports for N, P and K by Weisany et al. (2013), Lambers et al. (2014) and Wang et al. (2013) respectively.

Micronutrients take the same trend of macronutrients for yield parameters, micronutrients involved in many biological processes in the plant, especially the antioxidants formation processes in the plant where the micronutrients application increased the enzyme activity which formed the antioxidants. The micronutrients functions in plant for Fe, Mn, Zn, and B were reported by Barberona et al. (2014), Mousavi et al. (2011), Hafeez et al. (2013) and Ganie et al., (2013). The biofertilizer has important roles for growth plant regulars and plant nutrition were stated by Basha et al. (2006) and Esitken et al., (2006), Abd El-Gawad (2014) and. Jan et al. (2014) The above results agreed with those obtained by Mehmet et al., (2008), Nourali et al. (2011), Jagtap et al. (2012), Hagagg et al. (2012) and Tekaya et al. (2013).

Regarding to the soil fertility effect on fruits yield of fig and olive trees, the initial nutrients at Table 1 were sufficient for some nutrients and insufficient of other some nutrients, during the rainy season, the fig and olive trees were absorbing the nutrients from the soil into the trees, where part of these nutrients consumed in the vegetative growth stage and the other part stored in the trees (stem and branches). After the end of the rainy season, water absorption from the soil was less and also nutrients movement was less within the trees and show drought symptoms on trees. Therefore, the supplemental irrigation water must be adding to plants by use the foliar fertilizers application which increased the nutrients movement in plant and provides the nutrients of plant requirements in each stage of plant growth. This is reflected on the fruit productivity and quality of figs and olive trees, it is clear, the importance of soil fertility on the fruit productivity and quality. And also the importance of foliar fertilization in the completion stages of plant growth and fruit yield of fig and olive trees under the conditions of the North West Coast soils. The previous results agreed with those obtained by Hagagg et al. (2012), Tekaya et al. (2013) and Malek and Sanaa (2013).

Effect of mineral and bio-fertilizers on nutrients contents of fig and olive plants:

Data in Table 5 showed that the nutrients concentration in leaves of both fig and olive plants increased with increasing NPK, micronutrients and bio-fertilizers rates. The variations between the studied treatments were significant, about NPK fertilizers induced higher increases of nutrients concentration of fig leaves than control treatment by about 28.2, 16, 21.5, 21.6, 30.4, 21 and $36.4 \%$ for N, P, K, $\mathrm{Fe}, \mathrm{Mn}, \mathrm{Zn}$ and $\mathrm{Cu}$ of fig leaves respectively, while being 31.3, 9.8, 16.4, 19, 
26.5, 21.7 and $24 \%$ of olive leaves. The micronutrients application increased the concentration of this studied nutrients above control treatment by about 25, 13.4, $16.2,17.3,24.5,16.1$ and $28.2 \%$ for $\mathrm{N}, \mathrm{P}, \mathrm{K}, \mathrm{Fe}, \mathrm{Mn}, \mathrm{Zn}$ and $\mathrm{Cu}$ of fig leaves respectively, while being 29, 7.3, 11.4, 15.4, 21.5, 19.1 and $16.5 \%$ of olive leaves. The bio-fertilizer achieved increases over control treatment by about 3.5, 11.4, 4.4, 8.6, 12.9, 4.6 and 7.7\% for N, P, K, Fe, Mn, $\mathrm{Zn}$ and $\mathrm{Cu}$ of fig leaves respectively, and being $4.7,4.9,1.6,8.2,5.1,7.1$ and $5.5 \%$ of olive leaves.

TABLE 5. Effect of the mineral and bio fertilizers applied on the nutrients content of figs leaves (average of the two seasons).

\begin{tabular}{|c|c|c|c|c|c|c|c|c|c|c|c|c|c|c|c|}
\hline \multirow{2}{*}{\multicolumn{2}{|c|}{ Treatments }} & \multicolumn{7}{|c|}{ Nutrients content in figs leaves } & \multicolumn{7}{|c|}{ Nutrients content in olive leaves } \\
\hline & & $\mathbf{N}$ & $\mathbf{P}$ & $\mathbf{K}$ & $\mathrm{Fe}$ & Mn & Zn & $\mathrm{Cu}$ & $\mathbf{N}$ & $\mathbf{P}$ & $\mathbf{K}$ & $\mathrm{Fe}$ & Mn & Zn & $\mathbf{C u}$ \\
\hline & & \multicolumn{3}{|c|}{$\mathrm{g} / \mathbf{1 0 0 g}$} & \multicolumn{4}{|c|}{$\mathrm{mg} / \mathrm{kg}$} & \multicolumn{3}{|c|}{$\mathrm{g} / \mathbf{1 0 0 g}$} & \multicolumn{4}{|c|}{$\mathrm{mg} / \mathrm{kg}$} \\
\hline & Control & 0.79 & 0.14 & 0.46 & 152 & 112 & 57 & 11 & \begin{tabular}{|l|}
0.69 \\
\end{tabular} & 0.16 & 0.41 & 159 & 65 & 18 & 7 \\
\hline \multirow{9}{*}{ i. } & $\mathrm{Bio}_{0} \mathrm{Fol}_{1}$ & 1.40 & 0.27 & 1.02 & 288 & 196 & 100 & 19 & 1.22 & 0.32 & 0.85 & 265 & 101 & 32 & 12 \\
\hline & $\mathrm{Bio}_{0} \mathrm{Fol}_{2}$ & 1.53 & 0.31 & 1.11 & 312 & 214 & 109 & 21 & 1.33 & 0.37 & 0.98 & 289 & 111 & 35 & 13 \\
\hline & $\mathrm{Bio}_{0} \mathrm{Fol}_{3}$ & 1.65 & 0.33 & 1.2 & 336 & 232 & 118 & 22 & \begin{tabular}{|l|}
1.44 \\
\end{tabular} & 0.41 & 1.05 & 312 & 120 & 38 & 14 \\
\hline & $\mathrm{Bio}_{0} \mathrm{Fol}_{4}$ & \begin{tabular}{|l|}
1.84 \\
\end{tabular} & 0.37 & 1.33 & 372 & 258 & 131 & 25 & \begin{tabular}{|l|}
1.60 \\
1.1
\end{tabular} & \begin{tabular}{|l|}
0.45 \\
\end{tabular} & 1.15 & 346 & 131 & 42 & 16 \\
\hline & $\mathrm{Bio}_{1} \mathrm{Fol}_{0}$ & 1.04 & 0.21 & 0.72 & 214 & 139 & 78 & 15 & \begin{tabular}{|l|}
1.00 \\
0.89 \\
\end{tabular} & 0.23 & 0.6 & 188 & 79 & 23 & 8 \\
\hline & $\mathrm{Bio}_{1} \mathrm{Fol}_{1}$ & 1.48 & 0.28 & 1.07 & 300 & 206 & 105 & 20 & \begin{tabular}{|l|}
1.28 \\
\end{tabular} & 0.34 & 0.89 & 279 & 106 & 34 & 13 \\
\hline & $\mathrm{BiO}_{1} \mathrm{Fol}_{2}$ & 1.61 & 0.33 & 1.17 & 328 & 226 & 115 & 22 & 1.40 & 0.39 & 1.03 & 302 & 116 & 37 & 14 \\
\hline & $\mathrm{Bio}_{1} \mathrm{Fol}_{3}$ & \begin{tabular}{|l|}
1.73 \\
\end{tabular} & 0.35 & 1.26 & 352 & 244 & 124 & 23 & \begin{tabular}{|l|}
1.51 \\
\end{tabular} & 0.43 & 1.11 & 329 & 126 & 40 & 15 \\
\hline & $\mathrm{Bio}_{1} \mathrm{Fol}_{4}$ & \begin{tabular}{|l|}
1.92 \\
\end{tabular} & 0.39 & 1.4 & 392 & 270 & 137 & 26 & 1.68 & 0.46 & 1.21 & 363 & & 44 & 17 \\
\hline \multirow{9}{*}{ 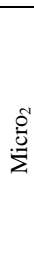 } & $\mathrm{Bio}_{0} \mathrm{Fol}_{1}$ & \begin{tabular}{|l|}
1.50 \\
\end{tabular} & 0.3 & 1.08 & 348 & 218 & 111 & 22 & 1.28 & 0.35 & 0.98 & 292 & 112 & 36 & 14 \\
\hline & $\mathrm{Bio}_{0} \mathrm{Fol}_{2}$ & 1.64 & 0.35 & 1.18 & 380 & 238 & 122 & 24 & 1.40 & 0.39 & 1.13 & 319 & 123 & 39 & 15 \\
\hline & $\mathrm{Bio}_{0} \mathrm{Fol}_{3}$ & 1.77 & 0.38 & 1.27 & 412 & 256 & 131 & 26 & \begin{tabular}{|l|}
1.51 \\
\end{tabular} & 0.44 & 1.22 & 346 & 132 & 42 & 16 \\
\hline & $\mathrm{Bio}_{0} \mathrm{Fol}_{4}$ & 1.96 & 0.41 & 1.41 & 456 & 284 & 146 & 29 & \begin{tabular}{|l|}
1.68 \\
1.61
\end{tabular} & 0.47 & 1.34 & 383 & 143 & 47 & 17 \\
\hline & $\mathrm{Bio}_{1} \mathrm{Fol}_{0}$ & 1.12 & 0.24 & 0.99 & 247 & 155 & 98 & 19 & \begin{tabular}{|l|}
0.99 \\
\end{tabular} & 0.28 & 0.7 & 207 & 87 & 26 & 9 \\
\hline & $\mathrm{Bio}_{1} \mathrm{Fol}_{1}$ & 1.57 & 0.32 & 1.13 & 368 & 228 & 117 & 23 & \begin{tabular}{|l|}
1.35 \\
\end{tabular} & 0.37 & 1.03 & 306 & 128 & 38 & 15 \\
\hline & $\mathrm{Bio}_{1} \mathrm{Fol}_{2}$ & 1.71 & 0.36 & 1.24 & 400 & 250 & 128 & 25 & \begin{tabular}{|l|}
1.47 \\
\end{tabular} & 0.41 & 1.19 & 336 & 137 & 41 & 16 \\
\hline & $\mathrm{Bio}_{1} \mathrm{Fol}_{3}$ & 1.85 & 0.4 & 1.33 & 432 & 270 & 137 & 27 & \begin{tabular}{|l|}
1.60 \\
\end{tabular} & 0.46 & 1.28 & 363 & 146 & 44 & 17 \\
\hline & $\mathrm{Bio}_{1} \mathrm{Fol}_{4}$ & 2.05 & 0.44 & 1.48 & 48 & 300 & 154 & 30 & \begin{tabular}{|l|}
1.77 \\
\end{tabular} & 0.48 & 1.4 & 403 & 152 & 49 & 18 \\
\hline \multicolumn{2}{|c|}{ LSD $_{0.05}$ Fol. } & 0.019 & 0.003 & 0.012 & 3.8 & 2.3 & 0.60 & 0.26 & 0.016 & 0.004 & 0.012 & 3.1 & $\frac{1}{1}$ & 0.38 & 0.15 \\
\hline \multicolumn{2}{|c|}{ LSD $_{0.05}$ Bio. } & 0.016 & 0.004 & 0.014 & 3.4 & 1.8 & 0.64 & 0.22 & 0.014 & 0.003 & 0.010 & 2.2 & 1.3 & 0.32 & 0.12 \\
\hline \multicolumn{2}{|c|}{$\begin{array}{l}\text { LSD }_{0.05} \\
\text { Micro. }\end{array}$} & 0.030 & 0.009 & 0.022 & 16.5 & 5.6 & 1.78 & 0.84 & 0.022 & 0.007 & 0.037 & 7.4 & 3.5 & 0.97 & 0.39 \\
\hline \multicolumn{2}{|c|}{$\mathrm{LSD}_{0.05} \mathrm{FxB}$} & 0.032 & 0.006 & 0.021 & 6.5 & 4.1 & 1.04 & 0.37 & \begin{tabular}{|l|}
0.028 \\
\end{tabular} & 0.007 & 0.021 & 5.3 & 1.9 & 0.66 & 0.26 \\
\hline \multicolumn{2}{|c|}{$\mathrm{LSD}_{0.05}$ FxM } & 0.026 & 0.005 & 0.017 & 5.3 & 3.3 & 0.85 & 0.31 & \begin{tabular}{|l|}
0.017 \\
\end{tabular} & 0.006 & 0.017 & 4.4 & 1.5 & 0.54 & 0.21 \\
\hline \multicolumn{2}{|c|}{ LSD $_{0.05} \mathrm{BxM}$} & 0.015 & 0.005 & \begin{tabular}{|l|}
0.020 \\
\end{tabular} & 4.7 & 2.6 & 0.91 & 0.32 & 0.020 & \begin{tabular}{|l|}
0.005 \\
\end{tabular} & \begin{tabular}{|l|}
0.014 \\
\end{tabular} & 3.2 & 1.8 & 0.45 & 0.17 \\
\hline \multicolumn{2}{|c|}{$\begin{array}{l}\text { LSD }_{0.05} \\
\text { 3factors }\end{array}$} & 6 & 0.009 & 0.030 & 9.2 & 5.7 & 1.47 & 0.53 & 0.039 & 0.010 & 0.030 & 7.6 & 2.6 & 0.94 & 0.36 \\
\hline
\end{tabular}

Data in Table 6 induced that the nutrients concentration in fruits of both fig and olive plants take the same trends of the nutrients behavior in leaves of both the studied plants.

The highest nutrients concentrations of leaves and fruits of the studied plants were achieved by superior treatment $\mathrm{Bio}_{1} \mathrm{Fol}_{4} \mathrm{Micro}_{2}$ when compared with the other studied treatments. The triple interaction showed the higher significant increases of nutrients content of leaves and fruits of both fig and olive plants.

The effect of the studied treatments on nutrients content of leaves and fruits of both the fig and olive plants were arranged as following: NPK fertilizers treatments $>$ micronutrients $>$ bio-fertilizers. These results were due to the important role of

Egypt. J. Soil Sci. 56, No. 1 (2016) 
macronutrients and micronutrients according to Weisany et al. (2013), Lambers et al. (2014) and Wang et al. (2013) for macronutrients functions in plant, Mousavi et al. (2011), Barberona et al. (2014) and Hafeez et al. (2013), for micronutrients functions in plant, while the bio-fertilizers roles in plant were stated by Basha et al., (2006) and Esitken et al. (2006), Abd El-Gawad (2014) and Jan et al. (2014). The above results agree with obtained by Sulaiman and Hassan (2011), Yousef et al. (2011) and Tekaya et al. (2013).

TABLE 6. Integration effect between mineral and bio fertilizers treatments on the nutrients contents of both figs and olive fruits (average of the two seasons).

\begin{tabular}{|c|c|c|c|c|c|c|c|c|c|c|c|c|c|c|c|}
\hline \multirow{3}{*}{\multicolumn{2}{|c|}{ Treatments }} & \multicolumn{7}{|c|}{ Nutrients content in figs fruits } & \multicolumn{7}{|c|}{ Nutrients content in olive fruits } \\
\hline & & $\mathbf{N}$ & $\mathbf{P}$ & $\mathbf{K}$ & $\mathbf{F e}$ & Mn & $\mathbf{Z n}$ & $\mathbf{C u}$ & $\mathbf{N}$ & $\mathbf{P}$ & $\mathbf{K}$ & $\mathbf{F e}$ & Mn & $\mathbf{Z n}$ & $\mathbf{C u}$ \\
\hline & & \multicolumn{3}{|c|}{$\mathrm{g} / \mathbf{1 0 0 g}$} & \multicolumn{4}{|c|}{$\mathrm{mg} / \mathrm{kg}$} & \multicolumn{3}{|c|}{$\mathrm{g} / \mathbf{1 0 0 g}$} & \multicolumn{4}{|c|}{$\mathrm{mg} / \mathrm{kg}$} \\
\hline \multicolumn{2}{|c|}{ Control } & 0.55 & 0.12 & 0.36 & 131 & 65 & 33 & 12 & 0.64 & 0.21 & 0.37 & 161 & 67 & 22 & 10 \\
\hline \multirow{9}{*}{$\stackrel{0}{\circ}$} & $\mathrm{Bio}_{0} \mathrm{Fol}_{1}$ & 0.88 & 0.24 & 0.68 & 206 & 111 & 53 & 19 & 1.01 & 0.39 & 0.79 & 286 & 110 & 41 & 17 \\
\hline & $\mathrm{Bio}_{0} \mathrm{Fol}_{2}$ & 0.96 & 0.26 & 0.75 & 222 & 122 & 55 & 20 & 1.11 & 0.4 & 0.91 & 329 & 120 & 44 & 18 \\
\hline & $\mathrm{Bio}_{0} \mathrm{Fol}_{3}$ & 1.04 & 0.28 & 0.8 & 238 & 132 & 59 & 21 & 1.20 & 0.43 & 0.99 & 354 & 130 & 48 & 20 \\
\hline & \begin{tabular}{|l|}
$\mathrm{Bio}_{0} \mathrm{Fol}_{4}$ \\
\end{tabular} & 1.15 & 0.31 & 0.89 & 269 & 144 & 66 & 22 & 1.33 & 0.48 & 1.07 & 388 & 144 & 53 & 22 \\
\hline & $\mathrm{Bio}_{1} \mathrm{Fol}_{0}$ & \begin{tabular}{|l|}
0.63 \\
\end{tabular} & 0.17 & 0.48 & 160 & 97 & 45 & 16 & 0.72 & 0.28 & 0.58 & 203 & 78 & 29 & 12 \\
\hline & $\mathrm{Bio}_{1} \mathrm{Fol}_{1}$ & 0.93 & 0.25 & 0.72 & 206 & 115 & 54 & 21 & 1.06 & 0.4 & 0.83 & 301 & 116 & 43 & 18 \\
\hline & $\mathrm{Bio}_{1} \mathrm{Fol}_{2}$ & 1.00 & 0.27 & 0.78 & 238 & 12 & 57 & 22 & 1.16 & 0.42 & 0.95 & 344 & 126 & 46 & 19 \\
\hline & $\mathrm{Bio}_{1} \mathrm{Fol}_{3}$ & 1.09 & 0.30 & 0.85 & 253 & 1 & 62 & 23 & 1.26 & 0.45 & 1.03 & 372 & 136 & 50 & 21 \\
\hline & $\mathrm{Bio}_{1} \mathrm{Fol}_{4}$ & 1.21 & 0.32 & 0.94 & 285 & 1 & 69 & 24 & 1.39 & 0.5 & 1.12 & 408 & 50 & 56 & 23 \\
\hline \multirow{9}{*}{$\frac{\mathscr{0}}{\Sigma}$} & $\mathrm{Bio}_{0} \mathrm{Fol}_{1}$ & 1.02 & 0.26 & 0.77 & 222 & 121 & 56 & 20 & 1.12 & 0.42 & 0.89 & 314 & 122 & 45 & 18 \\
\hline & $\mathrm{Bio}_{0} \mathrm{Fol}_{2}$ & 1.11 & 0.27 & 0.84 & 238 & 132 & 59 & 21 & 1.23 & 0.44 & 1.03 & 362 & 132 & 49 & 20 \\
\hline & $\mathrm{Bio}_{0} \mathrm{Fol}_{3}$ & 1.19 & 0.30 & 0.9 & 253 & 14 & 63 & 22 & 1.33 & 0.47 & 1.11 & 390 & 142 & 53 & 22 \\
\hline & $\mathrm{Bio}_{0} \mathrm{Fol}_{4}$ & 1.33 & 0.3 & 1 & 285 & & 70 & 23 & 1.47 & 0.52 & 1.21 & 428 & 158 & 58 & 24 \\
\hline & $\mathrm{Bio}_{1} \mathrm{Fol}_{0}$ & 0.72 & 0.20 & 0.55 & 173 & 11 & 50 & 18 & 0.83 & 0.32 & 0.74 & 223 & 87 & 32 & 13 \\
\hline & $\mathrm{Bio}_{1} \mathrm{Fol}_{1}$ & 1.07 & 0.26 & 0.81 & 233 & 132 & 58 & 21 & 1.18 & 0.43 & 0.94 & 332 & 128 & 47 & 19 \\
\hline & \begin{tabular}{|l|}
$\mathrm{Bio}_{1} \mathrm{Fol}_{2}$ \\
\end{tabular} & 1.16 & 0.29 & 0.88 & 253 & 139 & 61 & 22 & 1.29 & 0.46 & 1.08 & 380 & 138 & 51 & 21 \\
\hline & $\mathrm{Bio}_{1} \mathrm{Fol}_{3}$ & 1.26 & 0.31 & 0.95 & 269 & 150 & 66 & 23 & 1.39 & 0.5 & 1.16 & 411 & 150 & 55 & 23 \\
\hline & $\mathrm{Bio}_{1} \mathrm{Fol}_{4}$ & 1.39 & 0.35 & 1.05 & 285 & 164 & 74 & 24 & 1.54 & 0.55 & 1.24 & 449 & 166 & 61 & 25 \\
\hline \multicolumn{2}{|c|}{$\operatorname{LSD}_{0.05}$ Fol. } & 0.012 & 0.003 & 0.008 & 2.4 & 1.1 & 0.47 & 0.17 & 0.014 & 0.004 & \begin{tabular}{|l|}
0.011 \\
\end{tabular} & 4.4 & 1.25 & 0.49 & 0.20 \\
\hline \multicolumn{2}{|c|}{ LSD $_{0.05}$ Bio. } & 0.009 & 0.003 & \begin{tabular}{|l|}
0.007 \\
\end{tabular} & 2.0 & 1.5 & 0.54 & 0.20 & 0.010 & 0.004 & \begin{tabular}{|l|}
0.010 \\
\end{tabular} & 3.2 & 0.91 & \begin{tabular}{|l|l|}
0.38 \\
\end{tabular} & 0.14 \\
\hline \multicolumn{2}{|c|}{$\operatorname{LSD}_{0.05}$ Micro. } & 0.043 & 0.005 & 0.022 & 4.0 & 2.9 & 0.97 & 0.47 & 0.035 & 0.009 & 0.030 & 9.3 & 2.96 & 1.07 & 0.39 \\
\hline \multicolumn{2}{|c|}{$\mathrm{LSD}_{0.05} \mathrm{FxB}$} & 0.021 & 0.005 & 0.015 & 4.1 & 2.0 & 0.81 & 0.30 & 0.023 & 0.007 & 0.018 & 7.6 & 2.17 & 0.84 & 0.34 \\
\hline \multicolumn{2}{|c|}{$\mathrm{LSD}_{0.05} \mathrm{FxM}$} & 0.017 & 0.004 & 0.012 & 3.3 & 1.6 & 0.66 & 0.24 & 0.019 & 0.006 & 0.015 & 6.2 & 1.77 & 0.69 & 0.28 \\
\hline \multicolumn{2}{|c|}{$\operatorname{LSD}_{0.05} \mathrm{BxM}$} & 0.012 & 0.004 & 0.010 & 1.9 & 2.1 & 0.76 & 0.28 & 0.014 & 0.005 & 0.015 & 4.5 & 1.29 & 0.54 & 0.14 \\
\hline \multicolumn{2}{|c|}{$\operatorname{LSD}_{0.05} 3$ factors } & 0.030 & 0.007 & 0.021 & 5.8 & 2.8 & 1.14 & 0.42 & 0.033 & 0.010 & 0.026 & 10.7 & 3.07 & 1.19 & 0.48 \\
\hline
\end{tabular}

Effect mineral and bio-fertilizers on nutrients uptake by fruits of figs and olive trees

Data at Table 7 showed that nutrients uptake by fruits of fig and olive trees increased with increasing application of NPK, micronutrients and bio-fertilizers rates. The variations among these studied treatments were significant. NPK fertilizers increased the nutrients uptake of fig and olive fruits above control treatment by about $27.4,17,18.8,18,21.2,33.8$ and $30.8 \%$ for $\mathrm{N}, \mathrm{P}, \mathrm{K}, \mathrm{Fe}, \mathrm{Mn}$, $\mathrm{Zn}$ and $\mathrm{Cu}$ of fig fruits respectively, while being 28.3, 15.5, 18.3, 16, 24.1, 23.6 and $29.2 \%$ of olive fruits. Micronutrients treatments recorded increases of these nutrients uptake of fig fruits above control treatment by about 25.2, 12.8, 15.2, 13.7, 15.9, 30.4 and $22.6 \%$ for $\mathrm{N}, \mathrm{P}, \mathrm{K}, \mathrm{Fe}, \mathrm{Mn}, \mathrm{Zn}$ and $\mathrm{Cu}$ respectively, and being $24.9,11.7,14.4,12.3,19.2,19.3$ and $21.8 \%$ of olive fruits.

Bio-fertilizers achieved increases of nutrients uptake over control treatment by about 7.6, 5.6, 8.3, 10.4, 8.7, 16.4 and $3.2 \%$ for $\mathrm{N}, \mathrm{P}, \mathrm{K}, \mathrm{Fe}, \mathrm{Mn}, \mathrm{Zn}$ and $\mathrm{Cu}$ of figs fruits respectively, and $0.8,7.8,8,6.5,13,8.7$ and $9.2 \%$ of olive fruits.

Egypt. J. Soil Sci. 56, No. 1 (2016) 
The studied treatments were sort descending to order nutrients uptake as following: NPK > micronutrients > bio-fertilizers. The highest nutrients uptake of figs and olive fruits were achieved these with superior treatment $\mathrm{Bio}_{1} \mathrm{Fol}_{4} \mathrm{Micro}_{2}$ when compared with the other studied treatments. The triple interaction showed the highest significant increases of nutrients uptake of both figs and olive fruits than the other interactions. This result may be due to the job role of bio-fertilizers, it is regular plant growth and fruits production of the figs and olive plants. The previous results agree with obtained by Yousef et al. (2011) Barranco et al. (2010) and Sulaiman and Hassan (2011).

TABLE 7. Effect of the mineral and bio fertilizers applied on the nutrients uptake of both fig and olive fruits (average of the two seasons).

\begin{tabular}{|c|c|c|c|c|c|c|c|c|c|c|c|c|c|c|c|}
\hline \multirow{3}{*}{\multicolumn{2}{|c|}{ Treatments }} & \multicolumn{7}{|c|}{ Nutrients uptake in figs fruits } & \multicolumn{7}{|c|}{ Nutrients uptake in olive fruits } \\
\hline & & $\mathbf{N}$ & $\mathbf{P}$ & $\mathbf{K}$ & $\mathbf{F e}$ & Mn & $\mathbf{Z n}$ & $\mathbf{C u}$ & $\mathbf{N}$ & $\mathbf{P}$ & $\mathbf{K}$ & $\mathbf{F e}$ & Mn & $\mathbf{Z n}$ & $\mathbf{C u}$ \\
\hline & & \multicolumn{3}{|c|}{$\mathrm{kg} / \mathrm{fed}$} & \multicolumn{4}{|c|}{$100 \mathrm{~g} / \mathrm{fed}$} & \multicolumn{3}{|c|}{$\mathrm{kg} / \mathrm{fed}$} & \multicolumn{4}{|c|}{$100 \mathrm{~g} / \mathrm{fed}$} \\
\hline \multicolumn{2}{|c|}{ Control } & 9 & 1.9 & 6 & 2.1 & 1.0 & 0.53 & 0.19 & 3.2 & 1.1 & 1.9 & 0.8 & 0.3 & 0.11 & 0.05 \\
\hline \multirow{9}{*}{$\sum^{\circ}$} & $\mathrm{Bio}_{0} \mathrm{Fol}_{1}$ & 32 & 8.6 & 24 & 7.4 & 4.0 & 1.91 & 0.68 & 11.3 & 4.4 & 8.8 & 3.2 & 1.2 & 0.46 & 0.19 \\
\hline & $\mathrm{Bio}_{0} \mathrm{Fol}_{2}$ & 52 & 14.0 & 41 & 12.0 & 6.6 & 2.97 & 1.08 & 19.4 & 7.0 & 15.9 & 5.8 & 2.1 & 0.77 & 0.32 \\
\hline & $\mathrm{Bio}_{0} \mathrm{Fol}_{3}$ & 78 & 21.0 & 60 & 17.9 & 9.9 & 4.43 & 1.58 & 30.6 & 11.0 & 25.2 & 9.0 & 3.3 & 1.22 & 0.51 \\
\hline & $\mathrm{Bio}_{0} \mathrm{Fol}_{4}$ & 112 & 30.1 & 86 & 26.1 & 14.0 & 6.40 & 2.13 & 47.1 & 17.0 & 37.9 & 13.7 & 5.1 & 1.88 & 0.78 \\
\hline & $\mathrm{Bio}_{1} \mathrm{Fol}_{0}$ & 13 & & 10 & & & & 0.32 & 3.8 & & 3.1 & 1.1 & 4 & & \\
\hline & $\mathrm{Bio}_{1} \mathrm{Fol}_{1}$ & 41 & 11.0 & 32 & 9.1 & 5 & 2.3 & 0.92 & 15.2 & 5.7 & 11.9 & 4.3 & 1.7 & 0.61 & 0.26 \\
\hline & $\mathrm{Bio}_{1} \mathrm{Fol}_{2}$ & 65 & 17.6 & 51 & 15.5 & 8.3 & 3.71 & 1.43 & 25.8 & 9.3 & 21.1 & 7.6 & 2.8 & 1.02 & 0.42 \\
\hline & $\mathrm{Bio}_{1} \mathrm{Fol}_{3}$ & 97 & 26.7 & 76 & 22.5 & 12.3 & 5.52 & 2.05 & 39.3 & 14.0 & 32.1 & 11.6 & 4.2 & 1.56 & 0.66 \\
\hline & $\mathrm{Bio}_{1} \mathrm{Fol}_{4}$ & 143 & 37.8 & 111 & 33.6 & 17.8 & 8.14 & 2.83 & 57.8 & 20.8 & 46.6 & 17.0 & 6.2 & 2.33 & 0.96 \\
\hline \multirow{9}{*}{ 总 } & $\mathrm{Bio}_{0} \mathrm{Fol}_{1}$ & 49 & 12.5 & 37 & 10.7 & 5.8 & 2.69 & 0.96 & 18.1 & 6.8 & 14.4 & 5.1 & 2.0 & 0.73 & 0.29 \\
\hline & $\mathrm{Bio}_{0} \mathrm{Fol}_{2}$ & 77 & 18.6 & 58 & 16.4 & 9.1 & 4.07 & 1.45 & 29.0 & 10.4 & 24.3 & 8.5 & 3.1 & 1.16 & 0.47 \\
\hline & $\mathrm{Bio}_{0} \mathrm{Fol}_{3}$ & 111 & 27.9 & 84 & 23.5 & 13.3 & 5.86 & 2.05 & 44.2 & 15.6 & 36.9 & 12.9 & 4.7 & 1.76 & 0.73 \\
\hline & $\mathrm{Bio}_{0} \mathrm{Fol}_{4}$ & 157 & 38.9 & 118 & 33.6 & & 8.26 & 2.71 & 62.6 & 25 & 51.5 & 18.2 & 6.7 & 2.47 & \\
\hline & $\mathrm{Bio}_{1} \mathrm{Fol}_{0}$ & 21 & 5 & 16 & & & & 0.52 & 6.1 & & 5.4 & 1.6 & 0.6 & 0.23 & .09 \\
\hline & \begin{tabular}{|c|}
$\mathrm{Bio}_{1} \mathrm{Fol}_{1}$ \\
\end{tabular} & 64 & 15.6 & 49 & 14.0 & 1.9 & 3.48 & 1.26 & 23.7 & 8.6 & 18.9 & 6.7 & 2.6 & 0.94 & 0.38 \\
\hline & $\mathrm{Bio}_{1} \mathrm{Fol}_{2}$ & 96 & 24.1 & 73 & 21.0 & 11.5 & 5.06 & 1.83 & 38.6 & 13.8 & 32.3 & 11.4 & 4.1 & 1.52 & 0.63 \\
\hline & $\mathrm{Bio}_{1} \mathrm{Fol}_{3}$ & 135 & 33.2 & 102 & 28.8 & 16.1 & 7.06 & 2.46 & 55.5 & 20.0 & 46.3 & 16.4 & 6.0 & 2.19 & 0.92 \\
\hline & $\mathrm{Bio}_{1} \mathrm{Fol}_{4}$ & 193 & 48.7 & 146 & 39.6 & 22.8 & 10.3 & 3.34 & 77.8 & 27.8 & 62.6 & 22.7 & 8.4 & 3.08 & 1.26 \\
\hline \multicolumn{2}{|c|}{ LSD $_{0.05}$ Fol. } & 7.1 & 1.44 & 5.0 & 1.19 & 0.74 & 0.31 & 0.09 & 2.75 & 0.96 & 2.35 & 0.79 & 0.29 & 0.11 & 0.04 \\
\hline \multicolumn{2}{|c|}{ LSD $_{0.05}$ Bio. } & 1.4 & 0.37 & 1.1 & 0.31 & 0.1 & 0.0 & 0.03 & 0.58 & 0.2 & 0.48 & 0.17 & 0.06 & 0.02 & 0.01 \\
\hline \multicolumn{2}{|c|}{ LSD $_{0.05}$ Micro. } & 2.4 & 0.63 & 1.9 & 0.53 & 0.29 & 0.1 & 0.04 & 1.02 & 0.36 & 0.83 & 0.30 & .11 & 0.04 & 0.02 \\
\hline \multicolumn{2}{|c|}{$\mathrm{LSD}_{0.05} \mathrm{FxB}$} & 2.0 & 0.53 & 1.6 & 0.44 & 0.26 & 0.11 & 0.03 & 0.82 & 0.30 & 0.68 & 0.24 & 0.09 & 0.03 & 0.01 \\
\hline \multicolumn{2}{|c|}{$\operatorname{LSD}_{0.05} \mathrm{FxM}$} & 3.5 & 0.89 & 2.6 & 0.75 & 0.41 & 0.18 & 0.06 & 1.44 & 0.51 & 1.18 & 0.42 & 0.16 & 0.06 & 0.02 \\
\hline \multicolumn{2}{|c|}{$\mathrm{LSD}_{0.05} \mathrm{BxM}$} & 4.2 & 1.08 & 3.2 & 0.92 & 0.50 & 0.23 & 0.07 & 1.76 & 0.63 & 1.44 & 0.52 & 0.19 & 0.07 & 0.03 \\
\hline \multicolumn{2}{|c|}{$\operatorname{LSD}_{0.05}$ 3factors } & 4.5 & 1.15 & 3.4 & 1.29 & 0.53 & 0.24 & 0.11 & 1.86 & 0.66 & 1.53 & 0.55 & 0.20 & 0.07 & 0.03 \\
\hline
\end{tabular}

Effect mineral and bio-fertilizers on the microbial in leaves of fig and olive trees:

The phyllosphere or plant leaf surface has many microorganisms. Microorganisms fixed nitrogen from atmospheric, produce plant growth regulators, sugars, amino acids, peptides, enzymes, vitamins, organic acids and nucleotides (Hirane and Upper, 2000).

Total microbial counts: Mixed bio-fertilization treatments recorded highest total microbial counts in phyllosphere of fig and olive compared with mineral fertilization treatments without bio-fertilizer foliar application. The foliar application of bio-fertilization treatments increased microbial counts by $30 \%$ relative to control (Table 8). Abd El-Gawad (2014) reported that microbial inoculants improved fertilization, increase the number and biological activity of desired microorganisms.

Egypt. J. Soil Sci. 56, No. 1 (2016) 
Azotobacter density: Data in Table 8 showed that the foliar application of mineral and bio-fertilizers increased the growth of Azotobacter density in the phyllosphere (surface leaves) of fig and olive. Azotobacter chrococcum was not only fixed nitrogen but also produced amino acids, organic acids, vitamins, antimicrobial substances and increased microbial community and plant growth (Revillas et al. 2005). The superior treatment was $\left(\mathrm{Bio}_{1} \mathrm{Fol}_{4}\right.$ with Micronutrients) the integration treatment between mineral fertilizer and bio-fertilizers which achieved highest fruits yield parameters, nutrients contents, biochemical contents total microbial contents and Azotobacter density contents. This result was due to the important role mineral and bio-fertilizers in plant and effect their on yield and quality of fig and olive fruits according to Weisany et al. (2013), Lambers et al. (2014) and Wang et al. (2013) for macronutrients roles in plant, Mousavi et al. (2011), Barberona et al. (2014), and Hafeez et al. (2013), for micronutrients roles in plant, while bio-fertilizers roles were decided by Basha et al. (2006) and Esitken et al. (2006), Abd El-Gawad (2014) and Jan et al. (2014).

TABLE 8. Effect mineral and bio-fertilizers on the microbial density in leaves of fig and olive trees.

\begin{tabular}{|c|c|c|c|c|c|}
\hline & \multirow[b]{2}{*}{ Treatments } & \multicolumn{2}{|c|}{ Figs trees } & \multicolumn{2}{|c|}{ Olive trees } \\
\hline & & $\begin{array}{l}\text { Total microbial } \\
\text { counts } \times 10^{2} \mathrm{cfu} / \mathrm{g}\end{array}$ & $\begin{array}{l}\text { Azotobacter } \\
\text { densities in } \\
\text { phyllosphere } \\
\times 10^{2} \text { cells/g }\end{array}$ & $\begin{array}{l}\text { Total microbial } \\
\text { counts } \times 10^{2} \mathrm{cfu} / \mathrm{g}\end{array}$ & $\begin{array}{c}\text { Azotobacter } \\
\text { densities in } \\
\text { phyllosphere } \\
\times 10^{2} \text { cells/g }\end{array}$ \\
\hline & Control & 15 & 0 & 19 & 0 \\
\hline \multirow{9}{*}{ 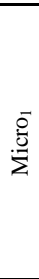 } & $\mathrm{Bio}_{0} \mathrm{Fol}_{1}$ & 18 & 0 & 22 & 0 \\
\hline & $\mathrm{Bio}_{0} \mathrm{Fol}_{2}$ & 21 & 0 & 24 & 0 \\
\hline & $\mathrm{Bio}_{0} \mathrm{Fol}_{3}$ & 23 & 0 & 27 & 0 \\
\hline & $\mathrm{Bio}_{0} \mathrm{Fol}_{4}$ & 25 & 0 & 29 & 0 \\
\hline & $\mathrm{Bio}_{1} \mathrm{Fol}_{0}$ & 41 & 3.5 & 46 & 3.8 \\
\hline & $\mathrm{Bio}_{1} \mathrm{Fol}_{1}$ & 43 & 3.9 & 51 & 4.1 \\
\hline & $\mathrm{Bio}_{1} \mathrm{Fol}_{2}$ & 46 & 4 & 52 & 4.2 \\
\hline & $\mathrm{Bio}_{1} \mathrm{Fol}_{3}$ & 48 & 4.1 & 54 & 4.4 \\
\hline & $\mathrm{Bio}_{1} \mathrm{Fol}_{4}$ & 49 & 4.3 & 57 & 4.6 \\
\hline \multirow{9}{*}{ 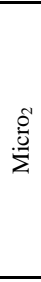 } & $\mathrm{Bio}_{0} \mathrm{Fol}_{1}$ & 23 & 0 & 26 & 0 \\
\hline & $\mathrm{Bio}_{0} \mathrm{Fol}_{2}$ & 26 & 0 & 29 & 0 \\
\hline & $\mathrm{Bio}_{0} \mathrm{Fol}_{3}$ & 28 & 0 & 31 & 0 \\
\hline & $\mathrm{Bio}_{0} \mathrm{Fol}_{4}$ & 29 & 0 & 34 & 0 \\
\hline & $\mathrm{Bio}_{1} \mathrm{Fol}_{0}$ & 41 & 4.7 & 49 & 4.8 \\
\hline & $\mathrm{Bio}_{1} \mathrm{Fol}_{1}$ & 46 & 4.9 & 53 & 5.3 \\
\hline & $\mathrm{Bio}_{1} \mathrm{Fol}_{2}$ & 49 & 5.2 & 55 & 6.2 \\
\hline & $\mathrm{Bio}_{1} \mathrm{Fol}_{3}$ & 52 & 5.6 & 57 & 6.3 \\
\hline & $\mathrm{Bio}_{1} \mathrm{Fol}_{4}$ & 55 & 5.8 & 58 & 6.4 \\
\hline \multicolumn{2}{|c|}{ LSD $_{0.05}$ Fol. } & 0.92 & 0.17 & 0.78 & 0.21 \\
\hline \multicolumn{2}{|c|}{ LSD $_{0.05}$ Bio. } & 1.89 & 0.36 & 2.08 & 0.39 \\
\hline \multicolumn{2}{|c|}{ LSD $_{0.05}$ Micro. } & 0.21 & 0.01 & 0.20 & 0.02 \\
\hline \multicolumn{2}{|c|}{$\mathrm{LSD}_{0.05} \mathrm{FxB}$} & 1.84 & 0.50 & 2.02 & 0.55 \\
\hline \multicolumn{2}{|c|}{$\operatorname{LSD}_{0.05} \mathrm{FxM}$} & 0.30 & 0.02 & 0.28 & 0.02 \\
\hline \multicolumn{2}{|c|}{$\operatorname{LSD}_{0.05} \mathrm{BxM}$} & 0.37 & 0.02 & 0.34 & 0.03 \\
\hline \multicolumn{2}{|c|}{ LSD $_{0.05} 3$ factors } & 0.52 & 0.03 & 0.49 & 0.04 \\
\hline
\end{tabular}


Effect of mineral and bio-fertilizers applied on biochemical of figs and olive trees

Data in Table 9 showed that the foliar application of micronutrients and NPK fertilizers with bio-fertilizer increased total phenols and total antioxidant in leaves and fruits of both fig and olive plants when compared with the control treatment.

The sugar content $\%$ and oil content $\%$ of fig and olive fruits increased with increasing NPK, micronutrients and bio-fertilizer application rates. Moreover, the studied factors effect ascending in order to biochemical of fig and olive trees as following: bio-fertilizers < micronutrients < NPK fertilizers. The most effective treatment was $\mathrm{Bio}_{1} \mathrm{Fol}_{4}$ with Micronutrients. In the other side, the concentrations of total phenols and total antioxidant activity of leaves and fruits of olive plants were higher than of figs plants. The above results agreed with those obtained by Sulaiman and Hassan (2011), Mujić et al.(2012), Malek and Sanaa (2013) and El-Sayed et al. (2014).

In conclusion, the yield components, total antioxidants, total phenols, nutrients contents and uptake of fig and olive trees increased with increasing the foliar application of NPK, micronutrients and bio-fertilizers rates. The studied treatments can be descending by arranged in order for yield parameters, nutrients content and uptake of both fig and olive trees as follows; NPK fertilizer> micronutrients fertilizers > bio-fertilizers > control. The total phenols, total antioxidants, total sugar $\%$ and oil content $\%$ of both fig and olive trees were tating the same trend of yield parameters and nutrients contents. The most effective treatment was $\mathrm{Bio}_{1} \mathrm{Fol}_{4}$ with $\mathrm{Micro}_{2}$ which achieved 17.33 ton fruits/fed (35trees/fed) and 7.94 ton fruits/fed (42 trees/fed) for fig and olive fruits, respectively. The triple interaction was the superior treatment for yield components, nutrients contents, nutrients uptake and biochemical of both fig and olive plants as well as increased total microbial counts and Azotobacter density in leaves of fig and olive trees. 
INFLUENCE OF FOLIAR APPLIED MINERAL AND BIO-FERTILIZERS

TABLE 9. Effect of foliar mineral and bio-fertilizers applied on total antioxidants and total phenols of both figs and olive plants.

\begin{tabular}{|c|c|c|c|c|c|c|c|c|c|c|c|}
\hline \multirow{4}{*}{\multicolumn{2}{|c|}{ Treatments }} & \multicolumn{5}{|c|}{ Figs trees } & \multicolumn{5}{|c|}{ Olive trees } \\
\hline & & \multirow{2}{*}{\multicolumn{2}{|c|}{$\begin{array}{c}\text { T. Antioxidants } \\
\mu \mathrm{g} \text { ASA } / \mathrm{ml}\end{array}$}} & \multirow{2}{*}{\multicolumn{2}{|c|}{$\begin{array}{c}\text { T. phenols } \\
\mu \mathrm{mol} \text { GalA/ml }\end{array}$}} & \multirow{3}{*}{$\begin{array}{l}\text { Sugar } \\
\% \mathrm{FW} \\
\text { Fruits }\end{array}$} & \multirow{2}{*}{\multicolumn{2}{|c|}{\begin{tabular}{|c|} 
T. Antioxidants \\
$\mu \mathrm{g} \mathrm{ASA} / \mathrm{ml}$ \\
\end{tabular}}} & \multirow{2}{*}{\multicolumn{2}{|c|}{$\begin{array}{c}\text { T. phenols } \\
\mu \mathrm{mol} \text { GalA/ml }\end{array}$}} & \multirow{3}{*}{$\begin{array}{c}\text { Oil } \\
\% \text { FW } \\
\text { Fruits }\end{array}$} \\
\hline & & & & & & & & & & & \\
\hline & & Leaf & Fruits & Leaf & Fruits & & Leaf & Fruits & Leaf & Fruits & \\
\hline & Control & 116 & 65 & 225 & 147 & 16.9 & 156 & 88 & 298 & 195 & 9.2 \\
\hline \multirow{9}{*}{$\frac{\overline{8}}{\dot{Z}}$} & $\mathrm{Bio}_{0} \mathrm{Fol}_{1}$ & 194 & 122 & 389 & 253 & 18.2 & 242 & 152 & 485 & 315 & 12.2 \\
\hline & $\mathrm{Bio}_{0} \mathrm{Fol}_{2}$ & 236 & 172 & 465 & 325 & 20.9 & 271 & 198 & 534 & 373 & 14.8 \\
\hline & $\mathrm{Bio}_{0} \mathrm{Fol}_{3}$ & 277 & 201 & 516 & 392 & 24.4 & 310 & 225 & 578 & 439 & 16.5 \\
\hline & $\mathrm{Bio}_{0} \mathrm{Fol}_{4}$ & 329 & 231 & 577 & 454 & 27.1 & 359 & 252 & 630 & 495 & 17.8 \\
\hline & $\mathrm{Bio}_{1} \mathrm{Fol}_{0}$ & 136 & 85 & 273 & 177 & 17.6 & 172 & 108 & 344 & 224 & 10.4 \\
\hline & $\mathrm{Bio}_{1} \mathrm{Fol}_{1}$ & 214 & 135 & 409 & 264 & 20.5 & 264 & 167 & 504 & 326 & 13.4 \\
\hline & $\mathrm{Bio}_{1} \mathrm{Fol}_{2}$ & 247 & 179 & 469 & 330 & 24.2 & 291 & 211 & 552 & 389 & 15.8 \\
\hline & $\mathrm{Bio}_{1} \mathrm{Fol}_{3}$ & 282 & 200 & 498 & 378 & 28.2 & 337 & 239 & 595 & 452 & 17.7 \\
\hline & $\mathrm{Bio}_{1} \mathrm{Fol}_{4}$ & 337 & 238 & 579 & 458 & 29.9 & 378 & 267 & 650 & 514 & 18.6 \\
\hline \multirow{9}{*}{ 递 } & $\mathrm{Bio}_{0} \mathrm{Fol}_{1}$ & 208 & 137 & 417 & 269 & 21.9 & 254 & 167 & 509 & 329 & 13.5 \\
\hline & $\mathrm{Bio}_{0} \mathrm{Fol}_{2}$ & 249 & 180 & 479 & 333 & 25.1 & 289 & 209 & 556 & 386 & 15.8 \\
\hline & $\mathrm{Bio}_{0} \mathrm{Fol}_{3}$ & 288 & 204 & 517 & 391 & 28.9 & 333 & 236 & 598 & 452 & 17.5 \\
\hline & $\mathrm{Bio}_{0} \mathrm{Fol}_{4}$ & 348 & 241 & 582 & 461 & 31.3 & 389 & 269 & 651 & 515 & 18.6 \\
\hline & $\mathrm{Bio}_{1} \mathrm{Fol}_{0}$ & 149 & 103 & 302 & 195 & 18.55 & 180 & 125 & 366 & 235 & 11.3 \\
\hline & $\mathrm{Bio}_{1} \mathrm{Fol}_{1}$ & 225 & 153 & 427 & 274 & 25.9 & 278 & 189 & 527 & 339 & 14.6 \\
\hline & $\mathrm{Bio}_{1} \mathrm{Fol}_{2}$ & 259 & 179 & 480 & 337 & 28.7 & 312 & 216 & 578 & 406 & 16.5 \\
\hline & $\mathrm{Bio}_{1} \mathrm{Fol}_{3}$ & 297 & 200 & 519 & 388 & 31.8 & 359 & 242 & 627 & 469 & 18.3 \\
\hline & $\mathrm{Bio}_{1} \mathrm{Fol}_{4}$ & 349 & 232 & 564 & 440 & 34.7 & 418 & 278 & 676 & 527 & 19.7 \\
\hline \multicolumn{2}{|c|}{ LSD $_{0.05}$ Fol. } & 3.3 & 2.5 & 5.1 & 4.6 & 0.22 & 3.4 & 2.6 & 5.2 & 4.8 & 0.14 \\
\hline \multicolumn{2}{|c|}{ LSD $_{0.05}$ Bio. } & 1.5 & 0.9 & 1.4 & 0.7 & 0.31 & 2.5 & 1.7 & 3.1 & 2.0 & 0.12 \\
\hline \multicolumn{2}{|c|}{ LSD $_{0.05}$ Micro. } & 3.1 & 1.7 & 2.9 & 1.5 & 0.94 & 4.9 & 2.9 & 5.6 & 3.4 & 0.22 \\
\hline \multicolumn{2}{|c|}{$\operatorname{LSD}_{0.05} \mathrm{FxB}$} & 5.7 & 4.4 & 8.8 & 8.0 & 0.38 & 4.4 & 4.6 & 9.0 & 8.3 & 0.25 \\
\hline \multicolumn{2}{|c|}{$\mathrm{LSD}_{0.05} \mathrm{FxM}$} & 3.5 & 3.6 & 7.2 & 6.5 & 0.31 & 4.9 & 3.7 & 7.3 & 5.1 & 0.20 \\
\hline \multicolumn{2}{|c|}{ LSD $_{0.05} \mathrm{BxM}$} & 1.4 & 0.9 & 2.0 & 0.7 & 0.44 & 3.5 & 1.7 & 4.4 & 2.0 & 0.12 \\
\hline \multicolumn{2}{|c|}{$\operatorname{LSD}_{0.05} 3$ factors } & 8.1 & 6.2 & 12.4 & 11.3 & 0.54 & 6.3 & 6.5 & 9.5 & 8.8 & 0.35 \\
\hline
\end{tabular}

$\mu \mathrm{g} \mathrm{ASA} / \mathrm{ml}=\mu \mathrm{g}$ of Ascorbic acid $/ \mathrm{ml}$ extract, $\mu \mathrm{mol} \mathrm{GalA} / \mathrm{ml}=\mu \mathrm{mol}$ of $\mathrm{Gallic}$ acid $/ \mathrm{ml}$ extract, T.=Total and FW=fresh weight 


\section{References}

Abd El-Gawad (2014) Response of wheat (Triticum astivum) yield to mineral and biofertilization under soil surface mulching conditions in the affected saline area. Egypt.J.of Appl.Sci. 29 (2).

Barberona, M., Dubeauxb, G., Kolbc, C., Isonoc, E., Zelaznyb, E. and G. Vert (2014) Polarization of iron-regulated transporter 1 (IRT1) to the plant-soil interface plays crucial role in metal homeostasis. PNAS, 111(22), 8293-8298.

Barranco, D., Hicran, E., Concepción, M.D., Angjelina, B. and Arquero, O. (2010) Factors influencing the efficiency of foliar sprays of monopotassium phosphate in the olive. International J. of Plant Production, 4 (3), 235-240.

Barrow, G.L. and Velthan, R.K.A. (1993) Cown \& Steel's , Mannual for the identification of medical bacteria. Cambridge Univ.Press.

Basha, S.A., Sarma, B.K., Singh, D.P., Annapurna, K. and Singh, U.P. (2006) Differential methods of plant growth-promoting rhizobacteria induce synthesis of phenylalanine ammonia-lyase and phenolic componts differentially in chickpea. Folia Microbiol. 51, 463-468.

Bergey's Manual of Determinative Bacteriology (1994) John G Hol, Noel R. Kriey, Peter H.A. Sneath, James T. Staley T.Williams (Ed.) $\left(9^{\text {th }}\right.$ ed.) Williams and Wilkins, Baltimore London.

Britto, D.T. and Kronzucker, H.J. (2008) Cellular mechanisms of potassium transport in plants. Physiologia Plantarum, ISSN 0031-9317:1-14.

Cechin, I. and Fumis, T.d.F. (2004) Effect of nitrogen supply on growth and photosynthesis of sunflower plants grown in the greenhouse. Plant Science 166 (2004) 1379-1385.

Ceulemans,T., Merckx, R., Hens, M. and Honnay, O. (2011) A trait-based analysis of the role of phosphorus vs. nitrogen enrichment in plant species loss across Northwest European grasslands. Journal of Applied Ecology, 48 (5), 1155-1163.

Conte, S.S. and Walker, E.L. (2011) Transporters contributing to iron trafficking in plants. Molecular Plant, 1-13.

Cottenie, A., Verlso, M., Kilkens, L., Velghe, G. and Camerlynck, R. (1982) Chemical Analysis of Plants and Soils. Lab. Agroch. State Univ. Gent, Belgium.

Eleiwa, M.E., Hamed, E.R. and Shehata, H.Sh. (2012) The role of biofertilizers and/or some micronutrients on wheat plant (Triticum aestivum L.) growth in newly reclaimed soil. Journal of Medicinal Plants Research, 6 (17) : 3359-3369.

El-Sayed, O.M., El-Gammal, O.H.M. and Salama, A.S.M. (2014) Effect of ascorbic acid, proline and jasmonic acid foliar spraying on fruit set and yield of Manzanillo olive trees under salt stress. Scientia Horticulturae, 176 (11), 32-37. 
Ercisli, S., Tosun, M. Karlidag, H. Dzubur, A. Hadziabulic, S. and Aliman, Y. (2012) Color and antioxidant characteristics of some fresh fig (ficus carica 1.) genotypes from northeastern turkey. Plant Foods Hum Nutr., 67, 271-276.

Esitken, A., Pirlak, L., Turan, M., Sahin, F., (2006) Effects of floral and foliar application of plant growth promoting rhizobacteria (PGPR) on yield, growth and nutrition of sweet cherry. Sci Hortic. 110, 324-327.

Expert, D., Franza, T. and Dellagi, A. (2012) Iron in Plant-Pathogen InteractionsMicrobe Associations, Springer Briefs in Biometals, DOI: 10.1007/978-94-0075267-5272.

Gajbhiye, R.P., Sharma, R.R. and Tewari, R.N. (2003) Effects of bio-fertilizers on the growth and yield parameters of tomato. Indian J.Horti., 60(4), 368-371.

Gomez, K.A. and A.A. Gomez (1984) Statistical Procedures for Agricultural Research $2^{\text {nd }}$ ed., Wiley, New York.

Hafeez, B.; Khanif, Y. M. and M. Saleem (2013) Role of Zinc in Plant Nutrition- A Review. American Journal of Experimental Agriculture, 3(2), 374-391.

Hagagg, L.F.; Abd-Alhamid, N.; Mustafa, N.S. ; Shahin, M.F.M. and S.E. El Hady (2012) Effect of different Nitrogen applications and organic matter on growth performance of Maraky olive seedlings. J. of Applied Sci. Res., 8 (4), 2071-2075.

Hill, G. Sawers, (2000) Azotobacter. In Encyclopedia of Microbiology $3^{\text {rd }}$ ed, Academic Press, New York, 2000, pp. 359-371

Horowitz, W. (Ed.) (2000) AOAC Official Methods of Analysis (17 ${ }^{\text {th }}$ ed., sections 50.1.21 (992.05), 45.2.03 (944.12), and 45.2.01 (960.46). Gaithersburg, MD: Association of Official Analytical Chemists International.

Jagtap, P.B., Gaikwad, S.P. and Bhagat, A.A. (2012) Contribution of micronutrient fertilizers in improving yield and quality of fig (ficus carica) and economics of their application. Ecology, Environment and Conservation, 18 (2), 303-308

James, C.S. (2004) Analytical Chemistry of Food. Seale- Hayne Faculty of Agriculture, Food and Land use, Department of Agriculture and Food Studies, University of Polymouth, UK, 1, 96-97.

Jan, K., Rather, A. M. ; Boswal, M.V. and Ganie, A.H. (2014) Effect of biofertilizer and organic fertilizer on morpho-physiological parameters associated with grain yield with emphasis for further improvement in wheat yield production (Bread wheat=Triticum aestivum L.). International Journal of Agriculture and Crop Sciences (IJACS),7(4),178-184

Kates, M., (1972) Techniques of Lipidology, Isolation, Analysis and Identification of Lipids. North Holland Publishing Company, Amsterdam, London.

Klute, A.A (1986) Methods of Soil Analysis. Part 1 2nd ed. American Society of Agronomy .Inc. Publishes, Madison, Wisconsin, USA. 
Lambers, H., Hayes, P.E., Laliberte, E., Oliveira, R.S. and Zemunik, G. (2014) The role of phosphorus in explaining plant biodiversity patterns and processes in a global biodiversity hotspot. In: Mucina, L., Price, J.N. \& Kalwij, J.M. (Eds.), Biodiversity and vegetation: patterns, processes, conservation, pp. 41-42. Kwongan Foundation, Perth, AU.

Maksoud, M.A., El-Shamma, M.S., Saleh, M.A., Zaied, N.S. and O.M. Hafez, (2012) Effect of Different Compost Sorts and Biofertilizers on Chemlali Olive Trees Grown in Calcareous Soil. Middle-East J. of Scientific Research, 12 (8), 1046-1049.

Maksoud, M.A., Saleh, M.A., El-Shamma, M.S. and Foua, A.A. (2009) The Beneficial Effect of Biofertilizers and Antioxidants on Olive Trees under Calcareous Soil Conditions. World J. of Agric. Sci., 5 (3), 350-352.

Malek, B. K. and Sanaa, M. (2013) Response of Arbequina olive tree to reasonable fertilization. Afr. J. Agric. Res., 8 (29), 3911-3920.

Mimoun, M. B., Ghrab, M., Ghanem, M. and Elloumi, O. (2008) Effects of potassium foliar spray on olive, peach and plum, Part 1: olive experiments. Optimizing Crop Nutrition No. $17,14-17$

Mousavi, S.R., Shahsavari, M. and Rezaei, M. (2011) A general overview on manganese (mn) importance for crops production. Australian Journal of Basic and Applied Sciences, 5 (9), 1799-1803.

Mujić, I., Dudas, S., Skutin, H.M., Perusic, D., Zeković, Z., Lepojević, Z., Radojković, M., Vidović, S., Milošević, S. and Mesic, E.O. (2012) Determination of antioxidant properties of fig fruit extracts (ficus carica 1.). ISHS Acta Horticulturae, 940,1,100,75677572 .

Nautiyal, C.S., (1999) An efficient microbiological growth medium for screening phosphate solubilizing microorganisms. FEMS Microbiology Letters, 170, 265- 270.

Osman, S.M. (2010) Effect of mineral, bio-NPK soil application of young olive trees and foliar fertilization on leaf and shoot chemical composition. Research Journal of Agriculture and Biological Sciences, 6 (3), 311-318.

Page, A.L., Miller, R.H. and Keeney, D.R. (1984) Methods of soil analysis. Part 2: Chemical and Microbiological Properties. Second edition. Agronomy J. 9: 2, Am. Soc. Agron. Inc., Soil Sci. Soc. Am. Inc. Pub. Madison, Wisconsin, USA.

Petrakis, C. (2006) Olive Oil Extraction. Mediterranean Agronomic Institute of Chania, 1, 13: 191-223.

Revillas, J. J., Rodelas, B., Pozo, C., Martinez-Toledo, M.V. and Lopez, J.G. (2005) Production of amino acids by Azotobacter vinelandii and Azotobacter chroococcum with phenolic compounds as sole carbon source under diazotrophic and adiazotrophic conditions. J. appl. Microbiology, 4, 421-425.

Rimmer; Smith (2009) Antioxidants in soil organic matter and in associated plant materials. European J. of Soil Sci. 60 (2), 170-175.

Egypt. J. Soil Sci. 56, No. 1 (2016) 
Rizzolo, A.C., Baldo, J. and Polesello, A. (1993) Application of high performance liquid chromatography to the analysis of niacin and biotin in Italian almond cultivars. J. of Chromatoghraphy, 553(1-2).

Sulaiman, G.M. and Hassan, S.H. (2011) Determination of Sugars and Mineral Salts in Fresh Figs of Iraqian Cultivars. Tikrit Journal of Pure Science, 16 (1), 48-50.

Tekaya, M., Beligh, M., Amani, B., Faouzi, A. ttia, Hechmi, C., Mohamed, D. and Hammami, M. (2013) Enhancement of Antioxidants in Olive Oil by Foliar Fertilization of Olive Trees. J. of the American Oil Chemists' Society, 90 (9), 1377-1386.

Thuler, D.S., Floh, E.I.S., Handro, W. and Barbosa, H.R. (2003) Plant growth regulators and amino acids released by Azospirillum sp. in chemically defined media. Letters in Applied Microbiology, 37, 174-178.

Vijayan, K., Chakraborti, S.P. and Ghosh, P.D. (2007) Foliar application of Azatobactor chroococcum increases leaf yield under saline conditions in mulberry (Morus spp.). Sci. Hortic. 113, 307-311.

Wang, M., Zheng, Q., Shen, Q. and S. Guo (2013) The critical role of potassium in plant stress response. Int. J. Mol. Sci.,14, 7370-7390.

Weisany, W., Raei, Y. and Allahverdipoor, K.H. (2013) Role of Some of Mineral Nutrients in Biological Nitrogen Fixation. Bull. Env. Pharmacol. Life Sci., 2 (4), $77-$ 84.

Winget and Gold (2007) Effects of Effective Microorganisms ${ }^{\mathrm{TM}}$ on the Growth of (Brassica Rapa), Brigham Young University of Hawaii, Bio 493 Yuka Nakano.

Xiaohou, S.T. Min, J. Ping and Weiling, C. (2008) Effect of EM-bokashi application on control of secondary soil salinization, Water Science and Engineering, 1(4) (2008), 99-106

Yaz, S., Comlekcioglu, S. and Kuden, A.B. (2012) Quality characteristics and parthenocarpic properties of fig genotypes selected from the mediterranean and southeastern anatolia region. ISHS Acta Horticulturae 940, 1(100), 7567-7572.

Yousef, A.R.M., Mostafa, E.A.M. and Saleh, M.M.S. (2011) Response of olive seedlings to foliar sprays with amino acids and some micro elements. Agric. Biol. J. N. Am., 2 (7), 1108-1112. 


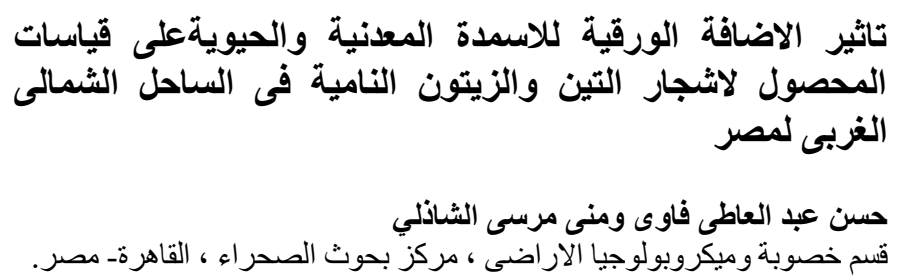

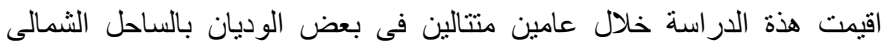

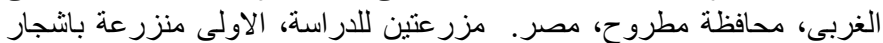
التين فى و ادى الجبالى و الموجودة مدرة عند الاحداثيات

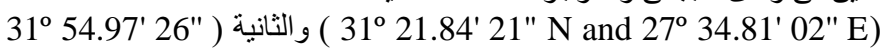
(N and 26 13.13' 37" E

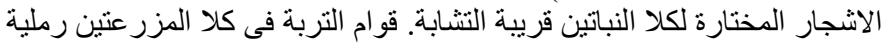

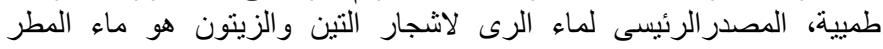

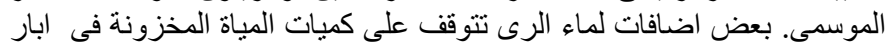

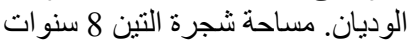

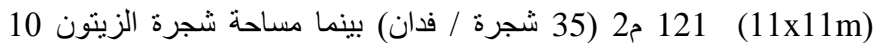

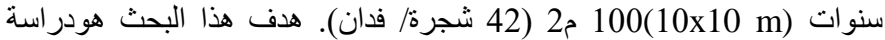

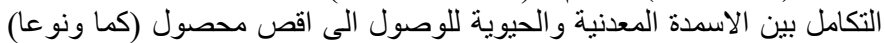

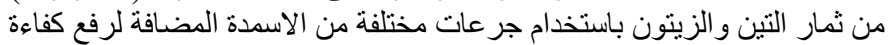
التسميد تحت ظروف التين ار اضى الساحل الثمالى الغربى.

النتائج المتحصل عليها تؤكد ان الاضافة الورقية لاسمدة العناصر الغذائية

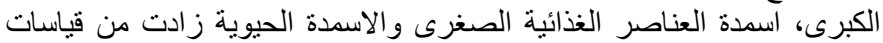

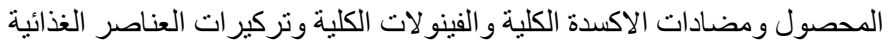
فى اوراق وثمار كلا من اشجار التين والزيتون.

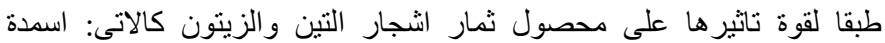

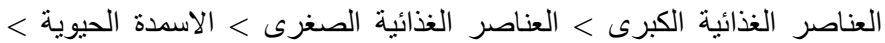

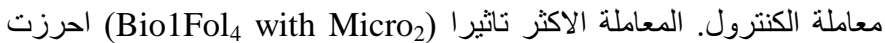

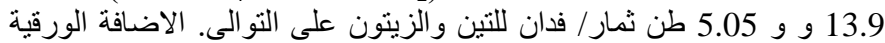

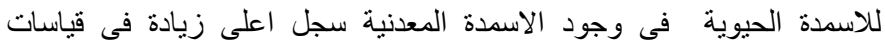

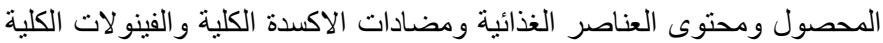

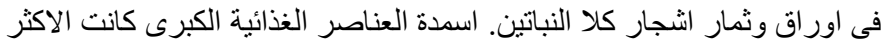

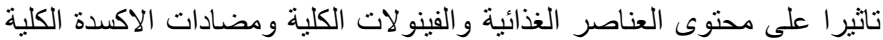

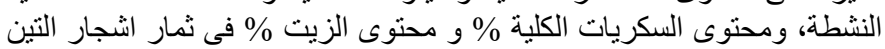

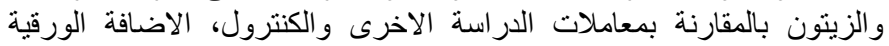

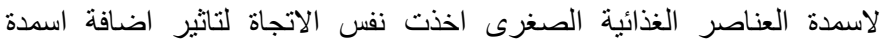

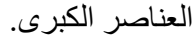

